\title{
O PRINCÍPIO CONSTITUCIONAL DO HABEAS CORPUS NO DIREITO CANÓNICO PORTUGUÊS
}

\section{THE CONSTITUTIONAL PRINCIPLE OF HABEAS CORPUS IN PORTUGUESE CANON LAW}

\author{
José Domingues \\ Universidade Lusiada Norte
}

\begin{abstract}
SUMARIO: I. INTRODUÇÃO.- II. AS CARTAS DE SEGURO NO DIREITO CANÓNICO PORTUGUÊS.- III. CONCLUSÃO.
\end{abstract}

Resumo: As cartas de seguro portuguesas assumem-se, cada vez mais, como uma das mais vetustas tradições jurídico-legislativas do principio constitucional do habeas corpus e, em simultâneo, uma cúspide da cultura juridica portuguesa. Durante os cinco séculos da sua vigência efectica ramificaram em duas tipologias: as cartas de seguro civis, sob a égide da Justiça civil monárquica, e as cartas de seguro canónicas, sob a égide da Justiça eclesiástica da Igreja. Para estas últimas pretende este estudo deixar aqui uma primeira abordagem e singelo adminículo a partir, sobretudo, do tratamento legislativo dispensado pelas várias Constituições Sinodais portuguesas, que foi cotejado com a legislação civil concordante.

Abstract: Portuguese insurance letters are increasingly considered as one of the oldest legislative-legal traditions of the constitutional principle of habeas corpus and simultaneously a cusp of the Portuguese legal culture. During the five centuries of its effective validity they ramified into two typologies: civil insurance letters, under the aegis of monarchical Civil Justice, and canonical insurance letters, under the aegis of the ecclesiastical Justice of the church. In respect to the latter, this study intends to leave here a first approach and simple support, mainly from the legislative treatment provided by the various Portuguese Synodal Constitutions, which was compared with the concordant civil legislation.

Palavras chave: habeas corpus, cartas de seguro, Direito canónico.

Key Words: habeas corpus, insurance letters, canon Law.

"Potest autem Securitas, de qua agimus definiti, ut sit quaedam licentia concessa Reo ab eo, qui potestatem habet concedendi, ut possit ad judicium venire, et ne carceretur virtute decreti capturae summarie editi, nisi quando alias de jure, et ipsius Securitatis natura debuerit carcerari..

"Todavia, a carta de seguro de que tratamos pode ser definida como sendo uma certa licença concedida ao réu por quem tem poder de a conceder, para que possa vir a juizo, e para que não seja encarcerado em virtude de um decreto de captura sumariamente emitido, a não ser quando, por Direito e pela própria natureza da carta de seguro, deve ser encarcerado".

1645 - Mateus Homem Leitão, Do Direito Lusitano. 


\section{INTRODUÇÃO.}

Uma das tradições jurídico-legislativas mais vetustas do princípio constitucional do habeas corpus poder-se-á radicar, desde o século XIII em diante, nas cartas de seguro instituidas e que circularam durante mais de cinco séculos consecutivos pelo espaço territorial do reino de Portugal $^{1}$. Não será despiciendo deixar aqui consignado que, mesmo antes do Parlamento inglês ter promanado o Habeas Corpus Act de 1679 -considerado, por alguma doutrina portuguesa, como o primeiro dos marcos jurídicos fundadores na génese dos direitos fundamentais ${ }^{2}$ - já o insigne jurisconsulto português Mateus Homem Leitão, no ano de $1645^{3}$, publicava um tratado doutrinal impar que ressuma uma ampla, longínqua, e bem assente tradição legislativa e jurisprudencial portuguesa, sem qualquer paralelo para a história do princípio constitucional do habeas corpus ${ }^{4}$.

Até à data, ainda não foi possivel chegar com a devida e cobiçada segurança científica à origem mais recôndita das cartas de seguro, vetusta e comummente enraizada num antiquíssimo costume não escrito do reino de Portugal $^{5}$. $\mathrm{O}$ mais

\footnotetext{
1 José Domingues, "As origens do principio de "habeas corpus" no pré-constitucionalismo português", Historia Constitucional, n. ${ }^{\circ} \quad 14, \quad 2013, \quad$ pp. $329-352 \quad$ (343-346), em http://www.historiaconstitucional.com (consultado no dia 10 de Setembro de 2013); Paulo Otero, Manual de Direito Administrativo, volume I, Almedina, 2013, p. 259, identifica as cartas de seguro portuguesas como um "antepassado lusitano do habeas corpus de origem britânica".
}

2 V. g., na esteira de Michael Sachs, José de Melo Alexandrino, Direitos Fundamentais Introdução Geral, 2. ${ }^{\text {a }}$ edição revista e actualizada, Principia, 2012, pp. 15-16: "podemos considerar que na génese próxima dos direitos fundamentais se encontram os seguintes marcos juridicos fundadores: o Habeas Corpus Act de 1679 e o Bill of Rights inglês de 1689, a Declaração de Direitos da Virginia de 1776 e a Declaração dos Direitos do Homem e do Cidadão de 1789”.

3 Esta obra conheceu várias edições -correspondentes aos anos de 1645, 1675, 1697, 1700, 1735, 1736 e 1745- que testemunham a subida acribia do seu autor e o elevado interesse e importância das matérias tratadas.

4 Mateus Homem Leitão, Do Direito Lusitano Dividido em Três Tratados: Agravos, Cartas de Seguro e Inquirições. Obra útil a todos os Professores de Leis e indispensável aos que trabalham nos tribunais, tradução do Latim de Fernando Ligório Vaz, prefácio e revisão técnica de António Manuel Hespanha, Fundação Calouste Gulbenkian, 2009, pp. 213-368 (com base na edição de 1745). A primeira edição do ano de 1645: De Iure Lusitano. Tomus primus in tres utiles tractatus divisus. 1. De Gravaminibus. 2. De Securitatibus. 3. De Inquisitionibus. Opus universis iurium professoribus utile, \& in foro versantibus maxime necessarium. Auctore Matthaeo Homem Leitão, Olim Bracharensis Curiae Primatialis Senatore, nunc Sanctae Inquisitionis Conimbricensis consultore Deputato. Illustrissimo D. Amplissimoque Praesuli D. Francisco de Castro in Regnis, \& Dominijs Portugalliae Inquisitori Generali dicatus. Cum facultate superiorum. Conimbricae. Ex Officina Emmanuelis de Carvalho Universitatis Typographi. Anno Domini M.DC.XLV., em http://webopac.sib.uc.pt/search S17*por?/Xmateus+homem+leit\%7bu00E3\%7do\&searchscope= 17\&SORT=D / Xmateus +homem+leit\%7bu00E3\%7do\&searchscope=17\&SORT=D\&SUBKEY=mateu s+homem+leit\%C3\%A3o/1\%2C3\%2C3\%2CX/1856\&FF=Xmateus+homem+leit\%7bu00E3\%7do\&se archscope $=17 \&$ SORT $=$ D\&3\%2C3\%2C $\% 2 \mathrm{C} 1 \% 2 \mathrm{C} 0$ (consultado no dia 18 de Novembro de 2013).

5 José Domingues, "As origens do princípio de "habeas corpus" no pré-constitucionalismo português”, op. cit., p. 335 (nota 22). O compilador da Reforma das Ordenações de D. Afonso V (1446), em comentário a uma lei de D. João I, a propósito das cartas de seguro deixou bem claro que "fomos certamente emformado que assy foi de longo tempo usado jeralmente em estes Regnos" Ordenaçoens do Senhor Rey D. Affonso V, Real Imprensa da Universidade, Coimbra, 1792 (facsimile da Fundação Calouste Gulbenkian, Lisboa, 1984/1998), Liv. III, Tít. 123, § 1-. 
verosímil é que este instituto jurídico derive do tronco comum do seguro régio que, ao longo da Idade Média ibérica, assumiu múltiplas e variadas facetas.

Morán Martín foi buscar o radical último para esse seguro régio peninsular à "paz", entendida como uma instituição própria do Direito germânico, que acabaria por se incrementar e moldar no Direito consuetudinário altomedieval peninsular. O Edictum Rothari (643) continua a ser o primeiro texto jurídico que preceitua um seguro régio concedido aqueles que vinham ao encontro de el-rei, prolongando-se, posteriormente, em vários preceitos castelhano-leoneses do século XII e princípios do século XIII - v.g., a incipiente consagração nos decretos das Cortes de Leão de 1188-. Asseverando a autora que "en el Derecho medieval, fronterizo con la Recepción del Derecho común, se ha reelaborado el concepto de paz general germánico para asumirlo el rey y establecer, además, paces especiales, todas ellas bajo su potestad, con un proceso muy similar tanto en Castilla como en Aragón"б.

A matriz jurídica leonesa e a influência da legislação curial peninsular nos primeiros momentos do ordenamento jurídico português são manifestas e sobejamente conhecidas $^{7}$, não só quanto às três assembleias tradicionalmente assinaladas (Leão-1017, Coiança-1055 e Oviedo-1115) ${ }^{8}$, mas também e em particular quanto às leis da cúria de Leão-1188. Duarte Nogueira não duvida que o acervo de 1188 serviu de estimulo ou inspiração determinante para a elaboração de algumas leis de D. Afonso II (1211), concluindo a este propósito que " $a$ importância das leis de 1188 parece ser claramente superior à das leis das demais cúrias"g.

A última ratio das pazes medievais de el-rei acaba por entroncar na acesa lide, que marca o período da Baixa Idade Média peninsular, contra a vindicta e a execução privada da justiça. Assim sendo, assevera Morán Martín, que "Alfonso $X$, tanto en las Partidas como en las Cortes de Zamora (de modo similar a lo que habia hecho Jaime I en 1247), ha logrado atraer hacia la jurisdicción real toda la materia relacionada con las paces privadas y sus consecuencias, que ya en este

\footnotetext{
6 Remedios Morán Martín e M $\mathrm{M}^{\mathrm{a}}$ Concepción Quintanilla Raso, "De la paz general al seguro regio. Para la comprensión jurídica de un concepto y su aplicación en la Castilla de los Reys Católicos”, En la España Medieval, vol 36, 2013, pp. 31-59 (42), em http://revistas.ucm.es/index.php/ELEM/article/view/41417 (consultado no dia 12 de Setembro de 2013).

7 José Domingues, "O Elemento Castelhano-Leonês na Formação do Direito Medieval Português", Cuadernos de Historia del Derecho, n. ${ }^{\circ}$ 21, 2014, pp. 215-216, em http://revistas.ucm.es/index.php/CUHD/article/view/47721 (consultado no dia 5 de Julho de 2015).

8 Alexandre Herculano, Portugalliae Monumenta Historica: A saeculo octavo post christum usque ad quintumdecimum - Leges et Consuetudines, vol. 1 fasc. 1, Academia das Ciências, Lisboa, 1856, pp. xii-xiv. Seguido pela manualística portuguesa actual, v. g., Nuno Espinosa Gomes da Silva, História do Direito Português - Fontes de Direito, 5. ${ }^{a}$ edição revista e actualizada, Fundação Calouste Gulbenkian, Lisboa, 2011, pp. 176-178; e Mário Júlio de Almeida e Costa, História do Direito Português, 5 . $^{\mathrm{a}}$ edição revista e actualizada, Almedina, Coimbra, 2011, pp. 206-207. Sobre o concílio de Coiança, vide a recensão à monografia de García-Gallo feita por Gonzálo Martínez Diez, "García-Gallo y el Concilio de Coyanza. Una monografia ejemplar”, Cuadernos de Historia del Derecho, n. ${ }^{\circ}$ 18, 2011, pp. 93-113, em http://revistas.ucm.es/index.php/CUHD/article/view/41512 (consultado no dia 7 de Otubro de 2013).

9 José A. Duarte Nogueira, Lei e Poder Régio I. As Leis de Afonso II, Lisboa, 2006, pp. 307 e 382. Cf. o anexo IV, coluna 10 .
} 
momento habian quedado prácticamente reducidas a los fijosdalgo"10. Em sequência e complemento -dentro da mesma publicação e em co-autoria- a investigação de Quintanilla Raso converge para o seguro régio como instrumento de governo dos reis católicos, em relação com a nobreza, integrado nessa enérgica e incessante procura da paz social ${ }^{11}$.

Esta derradeira tipologia de seguro, com a referida última ratio, também vigorou profusamente em Portugal sob a designação de carta de segurança real "a esta segurança he geralmente chamada Real"12_ concedida em resposta a um pedido formulado às justiças régias ou ao próprio monarca para que segurasse o peticionário e seu património contra a violência de outrem ${ }^{13}$. Homem Leitão, em pleno século XVII, continua a identificá-la como Carta Régia de seguro, "que os Magistrados Régios concedem a quem teme, com razão, que o inimigo lhe irá fazer uma ofensa"14.

Posto isto, tudo leva a crer que a evolução da paz geral germânica para as pazes especiais de el-rei se terá processado no reino de Portugal, em moldes bastante idênticos aos traçados para os reinos de Castela e Aragão ${ }^{15}$. Em relação a Portugal, cabe deixar aqui breve referência, $v . g$., à paz da casa (pax domestica) ou inviolabilidade do domicílio que surge disseminada pelas disposições dos foros breves e extensos e em preceitos de Afonso II (1211), presumivelmente, por influência das leis de Leão de 118816; aos forais dos primórdios da monarquia que, assiduas e simultaneamente, para além da referida paz da casa, regulamentam a paz do mercado $^{17}$, a paz do concelho (assembleia) e a paz da igreja ${ }^{18}$; a paz da corte surge especificamente acolhida em diploma de D. Dinis,

10 Remedios Morán Martín e $\mathrm{M}^{\mathrm{a}}$ Concepción Quintanilla Raso, "De la paz general al seguro regio", op. cit., p. 46.

11 Remedios Morán Martín e $\mathrm{M}^{\mathrm{a}}$ Concepción Quintanilla Raso, "De la paz general al seguro regio", op. cit., pp. 47-59.

12 Ordenaçoens do Senhor Rey D. Affonso V, op. cit, Liv. III, Tít. 122.

13 José Domingues, "As origens do principio de "habeas corpus" no pré-constitucionalismo português”, op. cit., pp. 340-341.

14 Mateus Homem Leitão, Do Direito Lusitano Dividido em Três Tratados, op. cit., p. 219.

15 Não deixará de ser relevante que o recurso de manifestación de las personas, que vigorou no reino de Aragão desde 1428 até 1592, seja reconhecido como o antecedente medievo mais imediato do habeas corpus.

16 José A. Duarte Nogueira, Lei e Poder Régio I. As Leis de Afonso II, op. cit., pp. 299-307.

17 Virginia Rau, Feiras Medievais Portuguesas: Subsídios para o seu estudo, Editorial Presença, Lisboa, 1982, pp. 41-49 (42): "a paz da feira, ou do mercado, protegia quem concorresse a essas reuniões mercantis, não só no local onde elas se realizavam, mas também na viagem de ida e de volta, e, consequentemente, abrangia também os estrangeiros que a elas viessem". A autora dá como exemplo a paz das feiras de Ponte de Lima (1125), Vila Mendo (1129), Guarda (1255) e Covilhã (1269).

18 José Domingues, "As origens do princípio de "habeas corpus" no pré-constitucionalismo português", op. cit., pp. 336-337 (bibliografia na nota 26); a esta bibliografia acresce o estudo de Cassiano Malacarne, "O direito de asilo nas igrejas e locais sagrados em Portugal no reinado de $D$. Dinis (1279-1325): os limites do perdão", em Práticas e Saberes no Medievo, Atas do Segundo Encontro Estadual de Estudos Medievais, Porto Alegre: Oikos, 2013, pp. 279-304. 
outorgado em Lisboa no dia 18 de Setembro de $1302^{19}$, que viu as severas penas corporais matizadas para penas pecuniárias, por lei sem data de D. João I (1385$1433)^{20}$; a paz real foi alargada por D. Dinis ao Estudo Geral por ele fundado ${ }^{21}$ e a paz do caminho é uma das imposições que surge manifesta no regimento dos meirinhos de el-rei, outorgado por D. Afonso III (1248-1279)22.

O rei medieval acaba por se assumir como o supremus iudex, que não conhece superior no seu reino -rex superiorem non recognoscens in regno suo est imperator-, mas está estritamente vinculado ao cumprimento da Justiça. Nesse amplo dever de administrar e executar Justiça -a par, v. g., dos casos da corte ${ }^{23}$,

19 "todo aquel que homem matar hu ElRey estever ou huma legoa arredor, ou sacar cuitello, ou espada, ou outra arma qualquer contra alguem e nom ferir com ella que lhe cortem o dedo polegar e deitem-no de toda sua terra fora pera todo sempre; e se ferir, cortem-lhe a mãao e deitem-no fora da terra pera sempre; e se matar, que moira porem; e que nenhuum dos que estas cousas fezerem nom se possa escusar de seu inmigo".

20 Ordenaçoens do Senhor Rey D. Affonso V, op. cit, Liv. V, Tít. 33 (Do que mata ou fere na Corte ou arredor della).

21 Por diplomas de 1 de Março de 1290: "porque das informações de algumas pessoas entendemos que alguns virão de várias partes ao nosso dito Estudo, segozarem de segurança de corpos e bens, Nós, querendo desenvolvê-lo em boas condições, prometemos, com a presente carta, plena segurança a todos os que nele estudarem ou queiram de futuro estudar" -Chartularium Universitatis Portugalensis, vol I (1288-1377), documentos coligidos e publicados por A. Moreira de Sá, Lisboa, 1966, doc. 5, pp. 11-12; 15 de Fevereiro de 1309: "todos os estudantes do nosso Estudo e também todos os que para ele vierem, seja qual for a região dos nossos Reinos de que provenham, recebemo-los sob a nossa protecção, com as suas pessoas, as suas coisas e seus familiares, mandando de modo especial e concretamente, a todos os juizes, alcaides e outros oficiais do nosso Reino, que protejam de toda a opressão ilicita os referidos escolares, os seus bens e os que os servem; e se fizerem o contrário, saibam que, sem dúvida alguma, hão-de incorrer na nossa indignação e que, além da pena que Nós imporemos aos transgressores, terão de restituir os prejuizos indevidamente causados aos referidos escolares" -Os primeiros estatutos da Universidade de Coimbra, introd. Manuel Augusto Rodrigues, Coimbra: Arquivo da Universidade, 1991-; e 3 de Setembro de 1310: "outrossy mando e tenho por bem que nenhuum nom faça mal nem força nem desaguisado aos scolares que a esse studo vierem ler nem a seus homens nem aos scripuães nem aaquelles que per razam do studo hi vierem e aquelles que lhe mal ou desaguisado fizesem ficariam por meus jmigos e peitariam os meus encoutos de seis mjl ssoldos"-Chartularium Universitatis Portugalensis, op. cit., doc. 33, pp. 55-56-.

22 José Domingues, "Os primórdios do Ius corrigendi em Portugal: Os meirinhos-mores de D. Afonso III", Revista Lusíada - Direito, n. ${ }^{\circ}$ 3, Universidade Lusiada do Porto, 2011, pp. 171-203 (189),

http://www.academia.edu/3099263/_Os_primordios_do_Ius_corrigendi_em_Portugal_Os_meirinh os-mores_de_D._Afonso_III_(consultado no dia 4 de Outubro de 2013).

${ }^{23}$ Num litígio entre o concelho e o bispo do Porto, em que este alega a ilegitimidade judicial do monarca com a doação feita por D. Teresa (em documento de 18 de Abril de 1120), D. Dinis deixou bem claro que "posto que doaçom podesse seer, que por ella pareçia que nom qujs dar nem tolher dessy as apellaçõoes nem a justiça do sanguy, nem outra jurdiçom e jus Real, nem outra justiça mayor, mais per ella pareçia que as rreteue para ssy e que the nom deu al, saluo as rrendas da ujlla per termos sabudos. E posto que tal doaçom fosse, que per ella podessem passar as apellaçõoes e as cousas suso ditas aa jgleia, o costume geeral e ho huso que foy e he sempre husado e guardado em contrayro por longo tempo nos meus Reynos tho tolhe. O qual costume he que nas doaçõoes que foram feitas mais compridamente pellos Reis meus anteçessores, assy a egreias come a pessoas e a hordeens Rellegiosas, que sempre os ditos Reis e eu husamos e costumamos de conhecer das cousas de suso ditas e de todas outras querellas que os concelhos ou cada huum delles fezerom dos senhores que ham doaçõoes dos Reis, assy na uilla do porto come nos outros logares do meu Senhoryo" -diploma de 13 de Maio de 1316, em Corpus Codicum Latinorum et 
apelação ${ }^{24}$ e correição ${ }^{25}$ - surge incluída a paz do rei, nas suas múltiplas facetas, inclusive as cartas de seguro para se estar, em liberdade, presente a juízo. Nesta linha de pensamento, talvez não seja demasiado precoce e audacioso conjecturarse aqui -por enquanto, como mera hipótese explicativa- que as cartas de seguro portuguesas tenham derivado e evoluido a partir da segurança concedida aqueles que vinham junto de el-rei, sobretudo, por causa de feitos de Justiça -explícita no édito de Rotário e posteriormente concretizada e desenvolvida pelos preceitos que saíram das cúrias castelhano-leonesas ${ }^{26}$.

É natural que a legitimidade para passar as cartas de seguro requeridas tenha evoluído ao longo dos tempos, sendo disputada pela multiplicidade de poderes jurisdicionais vigentes e estando adstrita à tipologia e aos circunstancialismos em que a conduta criminosa era praticada ${ }^{27}$. Importa reter, por ora, que os seguros em casos de homicídio -designados "casos de morte"- e outros considerados de maior gravidade $-v$. g., aleive, traição, sodomia, moeda falsa, heresia, arrombamento de cárcere ${ }^{28} \mathrm{e}$ resistência contra oficial da justiça- estavam reservados à outorga do próprio monarca e seus oficiais mores, fazendo parte da jurisdição suprema ou Justiça maior de el-rei ${ }^{29}$. Não obstante, el-rei D. João I (1385-1433) decretou a primeira ressalva, cedendo esta regalia ao condestável Nuno Álvares Pereira (1360-1431), que, mortis causa, se transmitiu aos duques de Bragança seus sucessores ${ }^{30}$; por alvará de 12 de Fevereiro de 1658, D. Afonso VI estendeu idêntica prerrogativa ao duque de Beja e marquês de Vila Real ${ }^{31}$; o arcebispo de Braga, por sua vez, conseguiu que D. Manuel

Portugalensium eorum qui in Archivo Municipali Portucalensi asservantur antiquissimorum iussu Curiae Municipalis editum, vol. I, Typis Oficinae Graphicae Portucalensis, Porto, 1891, p. 56-.

24 O mesmo D. Dinis, em lei de 1317, assevera que "em todalas doações que os Reys fazem a alguuns sempre fica esguardado aos Reys as appellações e justiça maior” -Ordenaçoens do Senhor Rey D. Affonso V, op. cit, Liv. III, Tít. 74, § 2-.

25 Conforme lei de 13 de Setembro de 1375: "Outro sy porque a correiçam he sobre toda jurdiçom como cousa que esguarda o maior e mais alto senhorio a que todos som sobgeitos, assy he apresa $e$ ajuntada ao principado e poderio do rey que per nenhuma guisa nom na pode de sy quitar" Ordenaçoens do Senhor Rey D. Affonso V, op. cit, Liv. II, Tít. 63, § 11-.

26 Remedios Morán Martín e $\mathrm{M}^{\mathrm{a}}$ Concepción Quintanilla Raso, "De la paz general al seguro regio”, op. cit., p. 41, nota 29.

27 Mateus Homem Leitão, Do Direito Lusitano Dividido em Três Tratados, op. cit., pp. 254-263, "Questão Quarta: Quem pode conceder as cartas de seguro de que tratamos, e se é obrigado a conceder de tal maneira que se pode provar da denegação".

28 "pela fuga, arrombando o cárcere (não, se por porta aberta), tem-se como provado o crime de quem foge" -em Mateus Homem Leitão, Do Direito Lusitano Dividido em Três Tratados, op. cit., p. 279-.

29 Ordenaçoens do Senhor Rey D. Affonso V, Real Imprensa da Universidade, Coimbra, 1792, Liv. 1, Tít. 23, § 25 (fac-simile da Fundação Calouste Gulbenkian, Lisboa, 1984/1998); Ordenaçoens do Senhor Rey D. Manuel, Coimbra, na Real Imprensa da Universidade, 1797, Liv. I, Tít. 39, § 21 e 26 (fac-simile da Fundação Calouste Gulbenkian, Lisboa, 1984); Codigo Philipino ou Ordenações e Leis do Reino de Portugal recopiladas por mandado d'El-rey D. Philippe I, $14^{\mathrm{a}}$ edição, Rio de Janeiro, Typographia do Instituto Philomathico, 1870, Liv. I, Tít. 58, § 40 e 41 (fac-simiel da Fundação Calouste Gulbenkian, Lisboa, 1985).

30 Conforme consta em documento de 10 de Dezembro de 1466 -Lisboa, IAN/TT - Gavetas, gav. 2, mç. 11, doc. 12-.

31 António Caetano de Sousa, Provas da História Genealógica da Casa Real Portuguesa, tomo V, Lisboa, 1746, p. 33, doc. 63. 
I, por alvará de 23 de Julho de 1512, lhe reconhecesse o mesmo direito ${ }^{32}$; e também ao conservador da Universidade de Coimbra é tributada a faculdade de outorgar cartas de seguros, mesmo em casos de morte ${ }^{33}$. O privilégio de os ouvidores da casa de Bragança, do infantado e do arcebispado de Braga poderem outorgar carta de seguro em casos de morte viria a ser abolido por alvará de 24 de Maio de $1688^{34}$.

O movimento do Ius commune iniciado com o Studium de Bolonha no primeiro quartel do século XII -integrado no ordenamento português, pela certa, na segunda metade do século XIII- fez com que, à semelhança da maioria das monarquias europeias, Portugal se pautasse, até finais do século XVIII, por uma multiplicidade de fontes de Direito vigentes em simultâneo no mesmo espaço geográfico e conformes entre si num parâmetro único de legalidade. A cartografia do poder jurisdicional, por seu turno, longe de uma centralização em torno do sumo representante do poder politico, apresenta-se retalhada por uma copiosidade de jurisdições periféricas $-v$. g., senhorial laica, eclesiástica, militar, do mar, da universidade, dos moedeiros e confessionais (reconhecidas aos judeus e aos muçulmanos)-. Neste mosaico policromático, o foro eclesiástico ombreou sempre, desde os primórdios da nacionalidade, com o foro civil. Nas laudas que se seguem tentarei gizar um esboço do papel preponderante desempenhado pelas cartas de seguro -o habeas corpus português- no âmbito jurídico-eclesiástico, que goteja curiosos e característicos pormenores da afinidade e antagonismo inerentes ao arquisecular relacionamento que esteve sempre latente entre os dois universos jurídicos do altar e do trono ${ }^{35}$.

32 Braga, AD - Ms. Rerum Memorabilium, vol. II, fl. 46v. Lisboa, IAN/TT - Feitos Findos, Casa da Suplicação, Liv. 72 (Livro das Extravagantes que até ao tempo presente há na Casa da Suplicação: Compilação feita por ordem do regedor Lourenço da Silva, por Duarte Nunes de Leão), fls. 132-132v, em http://digitarq.dgarq.gov.pt/details?id=4162662 (consultado no dia 7 de Outubro de 2013). Duarte Nunes de Leão, Leis Extravagantes collegidas e relatadas pelo licenciado Duarte Nunez do Liam per mandado do muito alto e muito poderoso Rei Dom Sebastiam nosso Senhor, por Antonio Gonçaluez, Lisboa, 1569, p. 104 (Edição "fac-simile» da Fundação Calouste Gulbenkian, Lisboa, 1987).

33 Estatutos da Universidade de Coimbra. Confirmados por el Rey nosso Senhor Dom Ioão o $4 .^{\circ}$ em o anno de 1653, Coimbra, 1654, Liv. 2, Tít. 27 (Do conservador e sua eleição e jurisdição) § 2: "O ditto Conseruador (...) ás pessoas de sua jurisdição poderá passar cartas de seguro, ainda que sejão casos de morte. E sendo as ditas cartas de seguro passadas pellos Corregedores da Corte, sempre o liuramento correrá diante o Conseruador; e terá assinaturas assi, e da maneira que as elles ora tem, e ao diante tiuerem"-em Estatutos da Universidade de Coimbra (1653), edição facsimilada, Coimbra, 1987-. Esta prerrogativa é muito anterior a esta data, conforme consta nos estatutos de 1559: o chanceler "E terá outrosi outro celo grande de cobre com as armas reais, que até agora esteve em poder do conservador, e com elle acellará todas as cartas de seguro" -Estatutos da Universidade de Coimbra (1559), com introdução e notas históricas e críticas de Serafim Leite, Acta Universitatis Conimbrigensis, Coimbra, 1963, p. 145, em http:/ / books.google.pt/books?id=INKMt4GSVqQC\&pg=PA145\&lpg=PA145\&dq=\%22estatutos +da+ universidade+carta+de+seguro $\% 22 \&$ source=bl\&ots $=$ dprFcPFQS\&sig=g9tKNBdGieubuoBDQKeG8R5OC2I\&hl=ptPT\&sa $=$ X\&ei=bgjDUZCRL8ue7Ab0pID4BA\&ved=0CC8Q6AEwAA\#v=onepage\&q=seguro\&f=false (consultado no dia 11 de Novembro de 2013).

34 Colecção de Legislação - D. Pedro II (1667-1706), Livro (1683-1700), p. 160. Cf. José Domingues, "As origens do principio de "habeas corpus" no pré-constitucionalismo português", op. cit., p. 349.

35 A título muito sumário, sobre estas relações entre o poder eclesiástico e o poder régio, $v$. g., Adelaide Pereira Millán da Costa, "Comunidades urbanas de senhorio eclesiástico: a divergente experiência da cidade do Porto e de Braga”, em Estudos em Homenagem ao Professor Doutor José 


\section{AS CARTAS DE SEGURO NO DIREITO CANÓNICO PORTUGUÊS.}

Nos alvores do século XVII já estava plenamente instituída, de iure e de facto, a legitimidade do foro eclesiástico para outorgar cartas de seguro em todos os casos crime -nas autorizadas palavras seiscentistas de Mateus Homem Leitão: "no foro eclesiástico, o Vigário geral do Bispo concede as cartas de seguro em todos os casos, como se dispõe em quase todas as Constituições dos Bispados e reconhece a Ordenação" (Q 4.21) ${ }^{36}$.

Muito antes desta franquia aberta culminar no Ius regni -das Constituições sinodais e das Ordenações do reino- pergaminhos mais longínquos acusam a legitimidade prelatícia para garantir a liberdade aos seus súbditos que quisessem estar seguros (em liberdade) perante a Justiça. No entanto, até ao final do período da Idade Média, essa legitimidade esteve sempre condicionada e limitada, nomeadamente, pelos casos de Justiça maior reservados à jurisdição régia.

As tensões entre o poder religioso e o civil, a propósito das cartas de seguro, já se revelam no início do século XIV. V. g., no acordo assinado com D. Dinis, a 9 de Agosto de 1309, o bispo da diocese de Lisboa (D. João) e o seu cabido queixam-se que el-rei não respeitava o foro eclesiástico quando algum clérigo pedia carta de segurança perante juiz leigo. O monarca -apoiando-se no Ius canonicum do Decreto de Graciano (c. 1140) e das Decretais de Gregório IX (1234)- admite que o juiz leigo possa dirimir a causa em que o clérigo pede segurança real perante juiz leigo se a parte contrária vier deduzir reconvenção ${ }^{37}$.

Mas, ao que tudo leva a crer $-c f$. a analogia, na quarta postura na lei das liberdades eclesiásticas de Outubro de 1309, com referência expressa à violência contra o leigo e a necessária concordância deste em segurar o clérigo ${ }^{38}-$, estas cartas inserem-se mais no âmbito das seguranças reais, destinadas a garantir protecção pessoal e patrimonial contra a violência de outrem. Afastando-se, por isso, do princípio constitucional de habeas corpus -a que subjaz uma garantia fundamental contra os abusos do poder público e não apenas contra a violência de outrem em particular- e do objecto imediato deste estudo.

Marques, vol. 1, Porto, 2006, pp. 77-85, em http://ler.letras.up.pt/uploads/ficheiros/4799.pdf (consultado no dia 11 de Setembro de 2013); Maria Helena da Cruz Coelho, "Bispos e Reis: oposições em torno de bens e jurisdições temporais", em Lusitania Sacra, $2^{a}$ série, n. ${ }^{\circ} 15$, Lisboa, 2003, pp. 279-287, em http://hdl.handle.net/10400.14/4463 (consultado no dia 11 de Setembro de 2013); José Marques, "O Senhorio de Braga no século XV: principais documentos para o seu estudo", em Bracara Augusta, vol. 46, Braga, 1997, pp. 5-136; Luís Miguel Duarte, "Um burgo medieval que muda de senhor. Episódios da vida do Porto medievo", em Ler História, $\mathrm{n}^{\circ}$ 5, Lisboa, 1985, pp. 3-16. Para uma síntese, cf. Joaquim Ramos de Carvalho, "Jurisdição Eclesiástica", em Dicionário de História da Igreja, dir. de Carlos M. Azevedo, Círculo de Leitores, Lisboa, 2001, vol. 3, pp. 41-43.

36 Mateus Homem Leitão, Do Direito Lusitano Dividido em Três Tratados, op. cit., p.261.

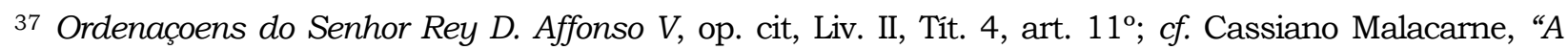
Reconventio: uma exceção canônica ao privilégio do foro eclesiástico e sua regulamentação em Portugal no começo do século XIV", em Revista OPSIS, Campus Catalão, vol. 12, n. ${ }^{\circ}$ 2, 2012, pp. 247-268, em http://www.revistas.ufg.br/index.php/Opsis/article/view/18355\#.Uka-Fdpdat8 (consultado no dia 23 de Setembro de 2013).

38 Livro das Leis e Posturas, Prefácio de Nuno Espinosa Gomes da Silva e leitura paleográfica e transcrição de Maria Teresa Campos Rodrigues, Lisboa, 1971, p. 130. 
O que não quer dizer que, sobretudo nos principios e em determinados circunstancialismos, as cartas de seguro não exercessem uma dúplice funcionalidade de protecção contra a prisão movida pelo poder instituído e, reflexamente, contra os interessados na vindicta privada. Talvez assim se entenda melhor que na lei dos casos em que os clérigos devem ser citados para responder na corte ou perante justiça secular, por um lado, se faça referência expressa às cartas de segurança outorgadas pelo monarca ou pelos seus meirinhos e corregedores das comarcas, "por rezão de algum maleficio, que tenha feito, pera estar seguro a direito perante alguum juiz leiguo" e, por outro lado, se remeta expressamente para o referido artigo feito em cortes entre os prelados e el-rei D. Dinis ${ }^{39}$.

As referências documentais às cartas de seguro canónico são coevas e até concomitantes às cartas de seguro civis. O agravamento de que se queixa o concelho do Porto contra o bispo e o cabido da cidade - "Outrossy diziam que os agrauauam poendolhes embargo e torua, defendendolhes que nom guaanhem cartas de mym [el-rei] para estarem seguros aa justiça"40_, numa contenda judicial que correu termos na corte e foi dirimida por D. Dinis por sentença definitiva de 13 de Maio de 1316, deixa poucas dúvidas que seriam cartas régias de "habeas corpus", para os cidadãos do Porto estarem seguros (em liberdade, sobretudo) à Justiça. O mais plausivel é que na base desta queixa esteja uma disputa, impulsionada pelo prelado portuense, à legitimidade outorgante de cartas de seguro aos cidadãos portuenses pelo próprio monarca. Por outras palavras, só é compreensivel que o prelado se opusesse às cartas de seguro passadas por el-rei D. Dinis se pretendesse avocar a si tal prerrogativa, no intuito de preservar ou alargar o privilégio de foro eclesiástico e garantir nesta matéria as liberdades da sua Igreja ${ }^{41}$.

A ombrear com a jurisdição secular, o privilegium fori eclesiástico, escudado sobretudo no argumento ratione personae, tentou sempre arrogar para si todas as questões judiciais em que uma das partes, pelo menos, fosse membro da Igreja. Por isso, as cartas de seguro não se revelam caso único ou sequer excepcional e não surpreende que, desde os tempos mais remotos, os prelados defendam a sua prerrogativa ou exclusividade de passar cartas de seguro às pessoas eclesiásticas para estarem seguras perante a Justiça canónica. Mas esta temática, inevitavelmente, acaba por se alastrar a zonas limitrofes e a criar atritos com a jurisdição civil.

D. Afonso IV chega a interditar os mestres das ordens militares e os prelados de passarem cartas de seguro - "sobresto tem por bem e manda que nem huum Mestre nem outro prelado que estado tenha de justiça logo seia mandado aos sobreditos prelados que non dem nem huma carta de segurança em nem huum

39 Ordenaçoens do Senhor Rey D. Affonso V, op. cit, Liv. III, Tít. 15, § 6. As entidades com legitimidade outorgante (rei, meirinhos, corregedores) e a referência expressa a estar seguro a Direito perante um juiz inculcam tratar-se de cartas de seguro que traduzem o princípio constitucional do habeas corpus.

40 Corpus Codicum Latinorum et Portugalensium, op. cit, pp. 55 e 58.

41 Mesmo não esquecendo que o bispo do Porto, par além da jurisdição espiritual, também tinha a jurisdição no temporal na cidade do Porto. 
feito"42-. Mas ter-se-á em linha de conta que neste acto legislativo do Bravo se refere, explicitamente, aqueles que têm estado de justiça de sangue. Uma vez que, em definitivo, os prelados continuaram a passar cartas de seguro aos seus súbditos para estarem seguros à Justiça canónica $-c f$. o artigo $13^{\circ}$ da concórdia de $1361^{43}$ e o artigo $1^{\circ}$ da concórdia de $1390 / 91^{44}$ - que os coevos monarcas mandam que lhe sejam respeitadas e não prendam, indevidamente, os clérigos seguros $^{45}$.

Mas a referida concórdia de 1361 não deixa, no entanto, de ressalvar os casos de "feito crime de morte d'homem, ou d'molher, ou em outro mui grave feito", em que a carta de seguro dos clérigos ficava condicionada a uma carta régia ratificativa, após a análise das respectivas inquirições devassas ${ }^{46}$. O conceito indeterminado dos outros feitos mui graves poder-se-á preencher com recurso à analogia dos casos de Justiça maior, reservada ao monarca. Esses casos constam explícitos no regimento dos corregedores das comarca, de 15 de Janeiro de 1340, que consagra uma reserva absoluta do monarca em relação às cartas de seguro em caso de morte de homem ou mulher, aleive, traição, sodomia, moeda falsa e heresia ${ }^{47}$. Os compiladores da Reforma das Ordenações de D. Afonso V (1446) mantêm a reserva nos mesmos parâmetros ${ }^{48}$.

Se nem os magistrados das comarcas - representantes directos do poder real junto das localidades- podiam segurar os autores desses feitos de maior gravidade, é compreensivel que o mesmo estivesse vedado aos prelados e seus representantes. Mas a restrição imposta à Justiça canónica vai-se alterar ao virar da página da Idade Média, nos finais da XV centúria e inícios da XVI, com a figura eminente de D. Diogo de Sousa a insurgir-se contra a limitação imposta pela mão estadual da monarquia.

A primeira manifestação legiferante, por parte do poder canónico, surge na $57^{\circ}$ constituição - "que se nam dem cartas de seguro, salvo aquelles que andavam ante do maleficio em abito e tonsura"- que saiu do sínodo portuense de 24 de Agosto de 1496. O coetâneo bispo do Porto (1495-1505), D. Diogo de Sousa, "consirando como somos obrigados a defenssar a justiça em nosso bispado", impôs aos seus vigários que só dessem cartas de seguros aos clérigos que, antes e depois de cometerem o malefício, andassem com coroa aberta e em hábito de clérigo beneficiado; considerando irritas, de nenhum valor e sem efeito as que fossem dadas em contrário. A ratio desta normativa canónica era evitar que a Igreja servisse de protecção aos malfeitores: na medida em que muito clérigos

42 Lisboa, IAN/TT - Feitos da Coroa, Núcleo Antigo 458, fl. 47v (Foros de Beja). Ainda se fala nas cartas de segurança passadas pelos ouvidores de el-rei, pelo que a decisão régia deve ser anterior ao regimento do corregedores de 1340.

43 Ordenaçoens do Senhor Rey D. Affonso V, op. cit, Liv. II, Tít. 5, artigo XIII.

44 Ordenaçoens do Senhor Rey D. Affonso V, op. cit, Liv. II, Tít. 6, artigo I.

45 Cf. José Domingues, "As origens do principio de "habeas corpus" no pré-constitucionalismo português”, op. cit., pp. 346-348.

46 Ordenaçoens do Senhor Rey D. Affonso V, op. cit, Liv. II, Tít. 5, artigo XIII.

47 Marcello Caetano, A Administração Municipal de Lisboa Durante a 1. a Dinastia (1179-1383), 2. ${ }^{a}$ Edição, Academia Portuguesa de História, Lisboa, 1981, pp. 158-174.

48 Ordenaçoens do Senhor Rey D. Affonso V, op. cit., Liv. 1, Tít. 23, § 25. 
seculares de ordens menores cometiam delitos graves e, para se esquivarem à pena corporal do foro secular, faziam-se "fraudulenter" raçoeiros de alguma igreja ou mosteiro e solicitavam cartas de seguro ao bispo e seus vigários para, contando com a piedade própria da Igreja, escaparem à justiça. "Pella qual cousa ha justiça hé deffraudada e emganada"49.

O fragmento das Constituições do Porto (1497) de D. Diogo de Sousa, à partida, não inculca qualquer discrepância nem afinidade com a legislação compilada nas coevas Ordenações de D. Afonso V (1446). O mesmo se não pode afirmar em relação a outro fragmento $\left(57^{\circ}\right)$ das sucessivas Constituições promulgadas por D. Digo de Sousa, ora na qualidade de arcebispo de Braga (1505-1532), que, pelo seu carácter precursor e impacto causado, vale a pena deixar aqui aspado na íntegra:

“Constituiçam .lvii. - Do tempo a que se ham de dar as cartas de seguro.

Porque em esta nossa corte hé custume de se darem cartas de seguro aas pessoas eclesiasticas cada e quando as pedem por se dizer contra elles que son culpados em mortes ou feridas dadas a alguumas pessoas, se acontece que feito ou maleficio impetra logo carta de seguro e com ella sem receo vam logo andar nos lugares inde as taaes mortes e delitos se fezerom, e por esta causa se geeram muitos scandalos, os quaaes quanto podermos avemos de desviar por assi seer honesto. E conformando-nos com o custume destes regnos defendemos a nosso provisor e vigairos que nom dem cartas de seguro a pessoas algumas por caso de morte, salvo seendo passado tempo de dous meses do tempo que se a morte aconteceo, e no caso de feridas seendo passados trinta dias do dia que forom dadas. E aos scrivãaes das taaes cartas mandamos que ponham em ellas que se guardem, scilicet, no caso das mortes, se os dous meses do tempo da morte som passados, e nos casos das feridas, se os trinta dias des o tempo do maleficio forem passados, e doutra maneira nam. E sendo dadas as taaes cartas contra forma desta nossa constituição, mandamos que se nam guardem, e que sem embargo dellas sejam presos os que em taaes casos forem achados em culpa tal per que mereçam seer pressos. E aos seguros por rezam de mortes defendemos que durando o tempo de seu livramento nom entrem nem estem nos lugares onde se as taaes mortes acontecerom sem special mandado do vigairo que de seu feito conhecer. E lugares entendemos cidades ou villas com seus arrabaldes, e nas terras chãas as freiguisias onde se acontecerom as dictas mortes. E fazendo o contrairo per esse mesmo feito seja sua carta de segurança nenhuma e possa seer preso como se a nom tivesse empetrada. E isto do entrar e estar do lugar se nom entemda no lugar onde o tal seguro estever a juizo quer seja nesta nossa cidade quer em outro lugar de nossa diocesi onde se acontecer

49 Constituiçõees que fez ho Senhor Dom Diogo de Sousa B/is]po do Porto, Távola Redonda: Centro de Estudos de História do Livro e da Edição, Lisboa, 1997 (Comemoração do V Centenário da introdução da imprensa no Porto, Fac-simile da edição do Porto : Of. de Rodrigo Álvares, 1497 -inc. da Biblioteca do Paço Ducal de Vila Viçosa, da Fundação Casa de Bragança, Res./45 Adq.-), 2 vol.s; Constituições de D. Diogo de Sousa. Impressas no Porto em 1497 por Rodrigo Álvares, Introdução, edição semidiplomática e lematização de José Barbosa Machado, Cadernos Culturais da Câmara Municipal, Vila Real, 2006 (2. ${ }^{a}$ edição, Braga, Edições Vercial, 2008 e ebook: Amazon, 2010); Synodicon Hispanum II. Portugal, edicion critica dirigida por Antonio Garcia y Garcia, Biblioteca de Autores Cristianos, Madrid, 1982, p. 400. 
nossos vigairos estarem e fazerem audiencias, porque nos taaes lugares thes hé necessario entrarem e estarem pera se delles fazer justiça"50.

O único exemplar conhecido destas Constituições não está datado, nem identifica impressor ou local de impressão ${ }^{51}$. A proposta mais coerente aponta para a sua aprovação no sínodo de Braga de 15 de Dezembro de 1505, com uma plausivel publicação no ano seguinte de 1506, pelo impressor Rodrigo Álvares ${ }^{52}$. A estar correcta esta datação, este fragmento canónico poderá estar na base da contenda entre o arcebispo de Braga e D. Manuel I por causa das cartas de seguro em casos de morte. El-rei acabou por reconhecer, em alvará de 23 de Julho de 1512, a competência ao ouvidor do arcebispo para passar cartas de seguro em feitos de morte 53 .

O fragmento das Constituições bracarenses, em certa medida, acaba por seguir de perto o que estava estabelecido pelo Direito civil do reino, mas sem deixar de cunhar alguns aspectos discordantes. Para evitar escândalos e se conformar ao costume do reino ficou definido um período de defeso para a outorga das carta de seguro, a contar desde o dia da prática do ilicito, de dois meses em caso de morte e trinta dias no caso de feridas abertas. O tempo de defeso em caso de morte é inferior ao previsto pelas Ordenações do reino vigentes. Em contrapartida, esta incipiente Lex ecclesiastica não ressalva os casos de legitima defesa em que, segundo a Lex civilis, deveria ser concedida carta de seguro imediata54. Por outro lado, a Lex ecclesiastica vai reforçar e explicitar a ideia civil de que os seguros que tivessem cometido crime de homicídio, no curso do processo, não deveriam entrar nem permanecer no lugar -cidade ou vila, inclusive seus arrabaldes, e as freguesias das terras não acasteladas- de cometimento do crime sem especial mandato do vigário da causa, salvo o local onde o seguro se deveria apresentar a juízo para se dele fazer Justiça.

No entanto, as duas ordens jurídicas -civil e canónica- desde a primeira metade do século XVI que tendem a convergir para uma legislação em moldes idênticos ou muito próximos, que, no século XVII, serão conducentes a remissões

50 Constituições de D. Diogo de Sousa. Publicadas em Synodicon Hispanum II. Portugal, edicion critica dirigida por Antonio García y García, Biblioteca de Autores Cristianos, Madrid, 1982, pp. 189-190.

51 Porto, BPM - X'-6-6-(2).

52 Synodicon Hispanum II. Portugal, edicion critica dirigida por Antonio García y García, Biblioteca de Autores Cristianos, Madrid, 1982 ; Helga Maria Jüsten, Incunábulos e PósIncunábulos Portugueses (ca. 1488 - 1518) (Em Redor do Material Tipográfico dos Impressos Portugueses), Tese de Doutoramento História, apresentada à Universidade Nova de Lisboa, Lisboa, 2006.

53 Braga, AD - Ms. Rerum Memorabilium, vol. II, fl. 46v. Duarte Nunes de Leão, Leis Extravagantes collegidas e relatadas pelo licenciado Duarte Nunez do Liam per mandado do muito alto e muito poderoso Rei Dom Sebastiam nosso Senhor, por Antonio Gonçaluez, Lisboa, 1569, p. 104 (Edição "fac-simile" da Fundação Calouste Gulbenkian, Lisboa, 1987). José Domingues, “As origens do principio de "habeas corpus" no pré-constitucionalismo português”, op. cit., pp. 348-349.

54 Cf. o Assento de 17 de Março de 1442 em Lisboa, IAN/TT - Duarte Nunes de Leão, Leis e ordenações, Núcleo Antigo 19 (Livro das Leis Extravagantes), fl. 244v. Ordenaçoens do Senhor Rey D. Affonso V, op. cit., Liv. III, Tít. 123, § 3 e Liv. V, Tít. 44, § 2. José Domingues, "As origens do principio de "habeas corpus" no pré-constitucionalismo português", op. cit., p. 350. 
expressas e directas, assumidas pelas próprias Constituições canónicas. As Constituições Sinodais do século XVI, posteriores às de Braga (1506), pautam-se pelo texto das Ordenações de D. Manuel I. Um cotejo do texto manuelino ${ }^{55}$ com o das Constituições de Évora, impressas no dia 22 de Outubro do ano de 1534, por mandado do cardeal D. Afonso ${ }^{56}$-arcebispo de Lisboa, perpétuo administrador do bispado de Évora e comendatário do mosteiro de Alcobaça- revela um vinculo umbilical entre ambas as legislações ${ }^{57}$.

Segue uma breve passagem e um confronto sumário a essa convergência, tendo por base os dois textos legais supra identificados, com o registo de eventuais variantes registadas em subsequentes Constituições Sinodais quinhentistas e seiscentistas dos outros bispados e arcebispados do reino $-v$. g., Constituições de Lisboa de 153758, Constituições de Braga de 153859, Constituições do Porto de 154160, Constituições de Coimbra de 154861, Constituições do Algarve de 155462, Constituições de Viseu de 155663, Constituições de Angra do Heroísmo de $1560^{64}$, Constituições do bispado de

55 O quinto liuro das Ordenações, Évora/Lisboa: Iacobo Cronberguer alemam, 11 de Março 1521, em http://purl.pt/12182 (consultado no dia 5 de Outubro de 2013); Ordenaçoens do Senhor Rey D. Manuel, Coimbra, na Real Imprensa da Universidade, 1797 (fac-simile da Fundação Calouste Gulbenkian, Lisboa, 1984).

56 Constituições do Bispado Deuora, Lisboa: por Germam Galharde, 22 Outubro 1534, fls. 7273, em http://purl.pt/14928 (consultado no dia 5 de Outubro de 2013). Pelo que me foi possivel apurar, é nestas Constituições quinhentistas de Évora que surge pela primeira vez o fragmento legislativo ora em análise. Deu resultado negativo a consulta efectuada às de Coimbra de 1521 Cõstituyçoões do Bispado de Coimbra: feytas pollo muyto reuerendo e magnifico senhor o señor dom Jorge dalmeyda: bispo de Coimbra Conde Darguanil \&.c, Segunda impressão editada pela Biblioteca da Universidade de Coimbra, Coimbra: Imprensa da Universidade, M. DCCCC. XIX, em https://archive.org/details/cstituyoes00cath (consultado no dia 5 de Outubro de 2013)- e às de Viseu de 1527 -Constituyçoes feytas per mandado do muyto Reuerendo señor ho señor dom Miguel da Silva bispo de Viseu y do co[n]selho de el Rey y seu escrivão da poridade [ordenadas e pubicadas em Sinodo celebrado aos dezasseis de Outubro de 1527]-.

57 O cotejo será apresentado em forma de tabela, para mais fácil se identificarem as diferenças e as semelhanças entre o texto das Ordenações Manuelinas (coluna 1) e o das Constituições Sinodais (coluna 2).

58 Constituicoens do arcebispado de Lixboa, Lisboa: por Germam Galharde, 22 Março 1537, fls. 79v-81, em http:/ / purl.pt/ 14665 (consultado no dia 13 de Outubro de 2013).

59 Constituições do arcebispado de Braga, Lisboa : per Germã Galharde: per mandado do principe o senhor ifante dom Anrique eleito arcebispo senhor de Braga primas das Espanhas, 30 Maio 1538, fls. 78-79, em http://purl.pt/14701 (consultado no dia 13 de Otubro de 1513).

60 Constituições sinodaes do bispado do Porto ordenadas pelo muito reuerendo e magnifico Senhor dom Baltasar Limpo bispo do dicto bispado etc., Porto: por Vasco Diaz Tanquo de Frexenal, 1 Março 1541, fls. 97-97v, em http://purl.pt/ 14687 (consultado no dia 13 de Outubro de 2013).

61 Constituições synodaes do bispado de Coimbra, Coimbra: per Ioão da Barreyra e Ioão Aluarez, 1548, fls. 91-91v, em http://purl.pt/4066 (consultado no dia 13 de Outubro de 2013).

62 Constituicoens do bispado do Algarue, Lisboa: em casa de Germão Galharde, 1554, fls. 83v84, em http://purl.pt/14796 (consultado no dia 13 de Outubro de 2013).

63 Constituyções synodaes do bispado de Viseu, Coimbra: per Ioam Aluares, 28 Maio 1556, fls. 76-77, em http://purl.pt/15042 (consultado no dia 13 de Outubro de 2013).

64 Constituições sinodaes do Bispado Dangra, Lisboa: per João Blavio de Colonia, 11 Janeiro 1560, fls. 84-85, em http:// purl.pt/15145 (consultado no dia 13 de Outubro de 2013). 
Lamego de $1563^{65}$, Constituições de Évora de $1565^{66}$, Constituições de Miranda de $1565^{67}$, Constituições do Funchal de $1585^{68}$, Constituições do Porto de $1585^{69}$, Constituições de Lisboa de 158870, Constituições de Coimbra de 159171, Constituições de Leiria de 160172, Constituições de Portalegre de 163273, Constituições de Braga de $1639^{74}$ etc.- que, com escassos ajustamentos, variantes ou acrescentos, reproduzem o primevo texto das Constituições de Évora de 1534.

(i) Os prazos de outorga das cartas de seguro, em caso de feridas e em caso de morte.

\footnotetext{
65 Constituições synodaes do bispado de Lamego, Coimbra: per Ioam de Barreyra, 1563, fls. 220-222,

em http://webopac.sib.uc.pt/search S17*por?/Xconstitui\{u00E7\}\{u00F5\}es+sinodais\&searchscope=1 7\&SORT=D/Xconstitui \{u00E7\}\{u00F5 $\}$ es + sinodais\&searchscope $=17 \&$ SORT $=$ D\&extended=1\&SUB KEY=constitui\%C3\%A7\%C3\%B5es+sinodais $/ 13 \% 2 \mathrm{C} 26 \% 2 \mathrm{C} 26 \% 2 \mathrm{CX} / 1856 \% \mathrm{FF}=\mathrm{Xconstitui}\{\mathrm{u} 00 \mathrm{E} 7$; u00F5 \}es + sinodais $\&$ searchscope $=17 \&$ SORT $=\mathrm{D} \& 22 \% 2 \mathrm{C} 22 \% 2 \mathrm{C} \% 2 \mathrm{C} 1 \% 2 \mathrm{C} 0$ (consultado no dia 13 de Outubro de 2013).
}

66 Constituições do arcebispado Deuora nouamente feitas por mandado do illustrissimo \& reuerendissimo señor dom Ioam de Mello arcebispo do dito arcebispado \&c., Évora: em casa de Andre de Burgos, 1565, fls. 79v-80v, em http://purl.pt/13348 (consultado no dia 13 de Outubro de 2013).

67 Constituições synodaes do bispado de Miranda, Lisboa: em casa de Francisco Correa, 1565, fls. 129v-130v, em http://purl.pt/14686 (consultado no dia 13 de Outubro de 2013).

68 Constituições synodaes do Bispado do Funchal feitas \& ordenadas por Dom Ieronymo Barreto, bispo do dito bispado, Lisboa: por Antonio Ribeiro, 1585, pp. 166-169, em http://purl.pt/14683 (consultado no dia 13 de Outubro de 2013).

69 Constituições Synodaes do Bispado do Porto ordenadas pelo muyto illustre... senhor Dom frey Marcos de Lisboa, bispo do dito bispado \&c., Agora nouamente acrecentadas com o Estilo da Iustiça, Coimbra: por Antonio de Mariz: á custa de Giraldo Mendez, liureiro, 1585, fls. 138v-139v, em http://purl.pt/15043 (consultado no dia 13 de Outubro de 2013).

70 Constituições do arcebispado de Lisboa assi as antigas como as extrauagantes primeyras $e$ segundas - Agora nouamente impressas, Lisboa: por Belchior Rodrigues: vendense na rua noua em casa de Ioam Lopez, 1588, fls. 84-85v, em http://purl.pt/14564 (consultado no dia 13 de Outubro de 2013).

71 Constituições synodaes do Bispado de Coimbra feitas \& ordenadas em synodo pello senhor Dom Affonso de Castel Branco bispo de Coimbra, conde de Arganil e por seu mandado impressas, Coimbra: per Antonio de Mariz, 1591, fls. 138v-140, em http://purl.pt/21747 (consultado no dia 13 de Outubro de 2013).

72 Constituiçoens synodaes do Bispado de Leiria / feytas \& ordenadas em synodo pello Senhor Dom Pedro de Castilho e por seu mandado impressas, Coimbra: por Manoel de Araujo, 1601, fls. 89-90v, em http://purl.pt/17440 (consultado no dia 13 de Outubro de 2013).

73 Constituições synodais do bispado de Portalegre / ordenadas e feitas pelo illustrissimo e Reverendissimo Sr. Fr. Lopo de Sequeira Pereira Bispo de Portalegre do Conselho de Sua Magestade, Portalegre: Jorge Roiz, 1632, fls. 210v-212, em http://purl.pt/19856 (consultado no dia 13 de Outubro de 2013).

74 Constituiçoens Sinodais do Arcebispado de Braga Ordenadas pelo Illustrissimo Senhro Arcebispo D. Sebastião de Matos e Noronha no Anno de 1639 E mandadas emprimir a primeira uez pelo Illustrissimo Senhor D. João de Sousa or Arsibispo es de Braga Primas das Espanhas em Ianeyro de 1697, Braga, 1697, pp. 520-525. 
Em relação aos prazos, a latente diferença de meses rapidamente encontra um patamar de entendimento entre ambas as ordens jurídicas, que vai fixar o defeso temporal em trinta dias para se outorgarem cartas de seguro nos casos de feridas abertas e três meses nos casos de morte ${ }^{75}$.

Para outorga de cartas de seguro nos casos de feridas abertas e pisaduras inchadas, em ambas as ordens jurídicas, desde o início que se impôs o decurso de um prazo de trinta dias - $c f$., a normativa civil de D. João $\mathrm{I}^{76}$ e a canónica de D. Diogo de Sousa ${ }^{77}$ - que se manteve sempre inalterado durante os séculos seguintes. Mas tal não se verificou em relação ao prazo em feitos de morte, senão vejamos.

$\mathrm{Na}$ reforma das Ordenações de D. Afonso V consta sempre o prazo de seis meses $^{78}$, que vinha do tempo de D. João I, pelo menos, e é referenciado numa determinação do infante regente D. Pedro, de 17 de março de $1442^{79}$. O mesmo prazo de seis meses ainda se mantém na autorização régia a D. Álvaro de Portugal, regedor da Casa da Suplicação (1473) para conceder cartas de seguro em feitos de morte e feridas abertas ${ }^{80}$. No entanto, no regimento do desembargador enviado com alçada à comarca da Beira, datado de 30 de Dezembro de 1495, já consta o prazo de três meses ${ }^{81}$; reiterado em diploma do dia 28 de Abril de 1496, que autoriza D. Álvaro de Castro, do Conselho de el-rei e governador da Casa do Civel de Lisboa, a dar cartas de segurança em feitos de morte e feridas abertas ${ }^{82}$. O que quer dizer que este prazo foi alterado, de seis para três meses, no lapso temporal entre a década de 70 e a década de 90 do século XV. Foi este o prazo que, por essa razão, veio a ser plasmado na primeira

75 A propósito do tempo em que podem ser requeridas e concedidas as cartas de seguro, $c f$. Mateus Homem Leitão, Do Direito Lusitano Dividido em Três Tratados, op. cit., pp. 264-271. Este autor resolve a questão de saber quantos dias estão contidos nos três meses com a ideia de que "qualquer mês tem trinta dias" (p. 268).

76 Ordenaçoens do Senhor Rey D. Affonso V, op. cit., Liv. III, Tít. 123, pr. e Liv. V, Tít. 44, § 1.

77 Constituições de D. Diogo de Sousa, op. cit., pp. 189-190.

78 Ordenaçoens do Senhor Rey D. Affonso V, op. cit., Liv. III, Tít. 123 e Liv. V, Tít. 44, § 2.

79 Lisboa, IAN/TT - Feitos Findos, Casa da Suplicação, Liv. 72 (Livro das Extravagantes que até ao tempo presente há na Casa da Suplicação: Compilação feita por ordem do regedor Lourenço da Silva, por Duarte Nunes de Leão), fls. 255v-256, em http://digitarq.dgarq.gov.pt/details?id=4162662 (consultado no dia 7 de Outubro de 2013).

80 Lisboa, IAN/TT - Feitos Findos, Casa da Suplicação, Liv. 72 (Livro das Extravagantes que até ao tempo presente há na Casa da Suplicação: Compilação feita por ordem do regedor Lourenço da Silva, por Duarte Nunes de Leão), fl. 56, em http://digitarq.dgarq.gov.pt/details?id=4162662 (consultado no dia 5 de Outubro de 2013); Lisboa, IAN/TT - Feitos Findos, Casa da Suplicação, Liv. 1 (Livro Antigo das Posses), fl. 30, em http://digitarq.dgarq.gov.pt/details?id=4162670 (consultado no dia 5 de Outubro de 2010); publicado em "Fragmentos de legislação escritos no livro chamado Antigo das Posses da Casa da Supplicação", Collecção de Livros Ineditos de Historia Portugueza, dos reinados de D. João I, D. Duarte, D. Affonso V e D. João II, publicados de ordem da Academia Real das Ciências de Lisboa, por José Correia da Serra, tomo III, Lisboa 1793, n. ${ }^{\circ}$ 18, p. 562, em http://archive.org/details/collecadeliv03corruoft (consultado no dia 5 de Outubro de 2013).

81 Luís Miguel Duarte, Justiça e Criminalidade no Portugal Medievo (1459-1481), Fundação Calouste Gulbenkian - Fundação para a Ciência e a Tecnologia, Coimbra [1999], doc. 93, p. 693.

82 Lisboa, IAN/TT - Chancelaria de D. Manuel, Liv. 33, fl. 108. 
edição das Ordenações de D. Manuel I, em $1512^{83}$, e se manteve na colectânea oficial das Ordenações seguinte, as Filipinas $(1603)^{84}$, até à sua revogação expressa pelo Decreto de 2 de Junho de $1830^{85}$.

As Constituições do arcebispo D. Diogo de Sousa (1506), ut supra, estabelecem um prazo de dois meses. No entanto, as Constituições de Évora de 1534 já adoptam o prazo de três meses em feito de morte e perseveram o prazo de trinta dias em feito de ofensas corporais. O discurso e os termos usados pelas últimas inculcam uma incontestada relação genealógica com o texto das Ordenações Manuelinas, que lhe terá servido de base textual.

\begin{tabular}{|c|c|}
\hline $\begin{array}{l}\text { OM (152 1) 5.49.pr - Que nom deem } \\
\text { Carta de segurança em caso de feridas } \\
\text { abertas atee passarem trinta dias e em } \\
\text { caso de morte atee tres meses }\end{array}$ & $\begin{array}{c}\text { CE (1534) } \mathbf{2 8} \text { - Das querelas e } \\
\text { denunciações } \\
\text { Constituiçam .x. Como se daram as } \\
\text { cartas de seguro de mortos e feridos }\end{array}$ \\
\hline $\begin{array}{l}\text { Mandamos que no caso de feridas } \\
\text { abertas, e sangoentas, ou pisaduras, ou } \\
\text { nodoas negras, e inchadas, se nom deem } \\
\text { Cartas de segurança atee serem passados } \\
\text { trinta dias, do dia que o maleficio foi feito } \\
\text { atee a dada desta carta, e que assi vaa } \\
\text { posto nessas Cartas de segurança, se os } \\
\text { ditos trinta dias sam passados \&c. E no } \\
\text { caso de morte de homem, ou molher, } \\
\text { Mandamos que se nom deem as ditas } \\
\text { Cartas de segurança atee serem passados } \\
\text { tres meses, contados do dia que a morte } \\
\text { acontecer; e se alguma Carta passar ante } \\
\text { do dito tempo sem Nosso especial } \\
\text { mandado, ou de quem pera isso Nossa } \\
\text { auctoridade teuer, nom seja guardada }{ }^{86} \text {. }\end{array}$ & $\begin{array}{l}\text { Conformandonos com ho costume, e } \\
\text { vsança geral destes regnos, e por euitar } \\
\text { grandes escandalos e inconuenientes que } \\
\text { do contrairo se seguiam Ordenamos e } \\
\text { mandamos que se nam dem cartas de } \\
\text { seguro a pessoas alguma por caso de } \\
\text { morte, saluo seendo passado tempo de } \\
\text { tres meses do dia que se ha morte } \\
\text { accontecer, e no caso de feridas abertas e } \\
\text { sanguentas, ou pancadas negras, e } \\
\text { inchadas, ou doutras feridas donde } \\
\text { parecerem alguns laidamentos } 87 \text {, se nom } \\
\text { dem cartas de seguro ate serem passados } \\
\text { trinta dias, do dia que ho maleficio for } \\
\text { feito, e mandamos aos scriuães (sob pena } \\
\text { de suspensam dos officios ate nossa } \\
\text { merce) que ponham nas dictas cartas } \\
\text { clausula que se guardem .a saber. no } \\
\text { caso da morte, se os tres meses do tempo } \\
\text { da morte sam passados, e no caso das } \\
\text { feridas ou pisaduras, se os trinta dias do } \\
\text { tempo do maleficio forem passados, ate } \\
\text { ha dada das dictas cartas, e doutra } \\
\text { maneira nam. }\end{array}$ \\
\hline
\end{tabular}

83 Ordenações Manuelina: Livros I a V: Reprodução em fac-símile da edição de Valentim Fernandes (Lisboa, 1512-1513), com Introdução de João José Alves Dias, Centro de Estudos Históricos da Universidade Nova de Lisboa, Lisboa, 2002, Liv. V, Tít. 42, fl. 32.

${ }^{84}$ Codigo Philipino, op. cit., Liv. V, Tít. 129, pr..

85 Colecção Completa até hoje dos Decretos da regência do Reino de Portugal Algarves e seus domínios nos anos de 1829 e 1830, na Imprensa do Governo, Angra, 1830, pp. 19-22.

86 Este texto, com escassas alterações, já vem do primeiro sistema das Ordenações Manuelinas: Ordenações Manuelina: Livros I a V: Reprodução em fac-símile da edição de Valentim Fernandes (Lisboa, 1512-1513), op. cit., Liv. V, Tit. 42, fls. 31v-32.

87 Curiosamente, a expressão "feridas abertas e sanguentas, ou pancadas negras, e inchadas, ou doutras feridas donde parecerem alguns laidamentos" está mais próxima da versão das Ordenações de 1512 do que da de 1521. 
O incipit desta constituição reitera e corrobora a tese do costume e usança geral do reino -que já surge referido nas Constituições de Braga (1506)- no cabouco das cartas de seguro. Esta menção traslada-se nas Constituições subsequentes e nas Constituições de Portalegre de 1632, v. g., refere-se expressamente o "antiquissimo costume deste Reyno"88. No mesmo sentido caminhava a doutrina coeva, v. g., a Allegatione 67, num. 1 de Tomé Vaz, editada pela primeira vez em $1612^{89}$.

(ii) A outorga imediata das cartas confessativas com defesa, em caso de morte.

O infante regente D. Pedro, reunido em relação com alguns do conselho e com os desembargadores e letrados de el-rei, no dia 17 de Março de 1442, "determinou que se não de<e> tal segurança ante dos seis meses passados por se euitar escandalo e se não dar mao exemplo"90. Mas para a imediata compilação das Ordenações (1446) transitou a opinião contrária vencida, porque "toda cousa que homem faça em defendimento de seu corpo, ainda que mate ou feira, toda he licita e premissa por Direito e ainda he geralmente per todos louvada e assi não tem justa rezam os feridos ou parentes dos mortos de se agravarem do mal que a elles ou a seus parentes seja feito per tal guisa e ja muito menos das cartas das

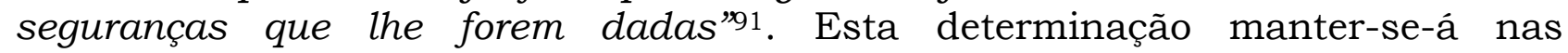
sucessoras Ordenações Manuelinas, mas com uma redacção diferente.

Foi esta derradeira versão manuelina que ditou o conteúdo para as Constituições de Évora de 1534.

\begin{tabular}{|c|c|}
\hline $\begin{array}{r}\text { OM (1521) } \mathbf{5 . 4 9 . 1}-\text { Que } \\
\text { de segurança em caso d } \\
\text { atee passarem trinta di }\end{array}$ & $\begin{array}{l}\text { 534) } \mathbf{2 8}-D \\
\text { denuncia }\end{array}$ \\
\hline $\begin{array}{l}\text { nça negua o male } \\
\text { onde elle confess } \\
\text { la por si alguma de } \\
\text { sa que por Dereitc } \\
\text { ções lhe deua } \\
\text { caso Mandamos qu }\end{array}$ & $\begin{array}{l}\text { tal carta de segu } \\
\text { porque no caso } \\
\text { maleficio e allega } \\
\text { tal que per dereitc } \\
\text { lhe sera dada } \\
\text { segurança em tod }\end{array}$ \\
\hline
\end{tabular}

88 Constituições synodais do bispado de Portalegre, op. cit., fl. 210v-212.

89 Thomae Valasci, Allegationes super varias materias: opus omnibus juris pontificii et cæsarei professoribus, judicibus, \& advocatis utile, \& necessarium, 3. a edição, Coimbra: apud Ludovicum Secco Ferreira, 1731, p. 248.

90 Lisboa, IAN/TT - Feitos Findos, Casa da Suplicação, Liv. 72 (Livro das Extravagantes que até ao tempo presente há na Casa da Suplicação: Compilação feita por ordem do regedor Lourenço da Silva, por Duarte Nunes de Leão), fls. 255v-256, em http://digitarq.dgarq.gov.pt/details?id=4162662 (consultado no dia 7 de Outubro de 2013).

91 Ordenaçoens do Senhor Rey D. Affonso V, op. cit., Liv. III, Tít. 123, § 3. 
dee Carta de segurança em todo tempo, mais alguum dia. sem aguardar mais alguum dia ${ }^{92}$.

De salientar que, sem surpresa, o texto canónico omite a remissão para as Ordenações régias. Em contrapartida, no final da constituição eborense consta uma remissão para os estilos do auditório desse bispado, no título do vigairo e parágrafo "E porque as cartas de seguro" 93; que se irá repetir noutras Constituições -v. g., as de Lisboa (1537): "e quanto ao modo que se deue teer com estes que as dictas cartas de seguro tomaram, se guardara ho que temos ordenado nos estilos do nosso auditorio Titulo do vigairo parrafo: $E$ porque ora fomos enformado"94_. Mais uma fonte de jurisprudência canónica a que vale a pena estar atento e tentar explorar no futuro.

(iii) Que os seguros, em caso de morte, não entrem nos lugares do maleficio durante o seu livramento.

A ideia de que os malfeitores não deviam entrar e permanecer nos lugares onde tinham cometido os actos de que estavam acusados, para se evitarem as represálias por parte dos ofendidos ou seus familiares, esteve sempre intrinseco às cartas de seguro, tanto no civil como no canónico. Mas com a diferença de a lei civil se limitar ao período entre a prática do acto e a concessão da carta de seguro. Ou seja, o arguido só não poderia entrar no locus delicti commissi enquanto lhe não fosse dada a respectiva carta de seguro $-v$. g., durante seis meses em feitos de morte e trinta dias em feitos de feridas abertas, na determinação do infante regente D. Pedro de 17 de março de $1442^{95}$ e nas Ordenações de D. Afonso V96-.

No entanto, esta norma e sua fundamentação foram expurgadas da imediata colectânea oficial das Ordenações Manuelinas. Por isso, a normativa canónica, para os seguros por razão de mortes, vai alicerçar-se no padrão estatuído pela constituição bracarense de D. Diogo de Sousa (1506) -ut supra-. Em suma, mantendo-se fiel a essa constituição, a Lei canónica: (i) impõe que os seguros não entrem no locus delicti commissi durante todo o tempo do processo judicial, salvo especial mandado do prelado ou seu vigário geral; (ii) os lugares para tal efeito são expressamente identificados com as cidades e vilas, inclusive os arrabaldes das muralhas, e as freguesias; (iii) em caso de desrespeito, a carta de seguro seria "quebrada" e perderia toda a sua eficácia; (iv) com ressalva, evidentemente, de o

92 Este texto, com escassas alterações, já vem do primeiro sistema das Ordenações Manuelinas: Ordenações Manuelina: Livros I a V: Reprodução em fac-símile da edição de Valentim Fernandes (Lisboa, 1512-1513), op. cit., Liv. V, Tit. 42, fl. 32.

93 Constituições do Bispado Deuora, op. cit., fl. 72v.

94 Constituicoens do arcebispado de Lixboa, op. cit., fl. 80.

95 Lisboa, IAN/TT - Feitos Findos, Casa da Suplicação, Liv. 72 (Livro das Extravagantes que até ao tempo presente há na Casa da Suplicação: Compilação feita por ordem do regedor Lourenço da Silva, por Duarte Nunes de Leão), fls. 255v-256, em http://digitarq.dgarq.gov.pt/details?id=4162662 (consultado no dia 7 de Outubro de 2013).

96 Ordenaçoens do Senhor Rey D. Affonso V, op. cit., Liv. III, Tít. 123, § 1. 
seguro ter que estar a juízo no local do delito, porque "em tal caso podera entrar $e$ estar no dicto logar pera seu liuramento e doutra maneira nam"97. A lei canónica é silente em relação aos seguros por ofensas à integridade física a outrem.

\begin{tabular}{l|l}
\hline CB (1506) & \multicolumn{1}{c}{ CE (1534) 28 - Das querelas e } \\
denunciaçós
\end{tabular}

As Constituições de Coimbra de 1548, no que vai ser seguida por outras homólogas, acrescentam que "se for cometido ho delicto nesta cidade, durando ho dito tempo nam passara polla rua, onde seu aduersario moraua, senam viuer na mesma rua'98. Sem o correspondente legislativo civil, neste ponto não seria desajustado o recurso ao Direito canónico a título subsidiário, uma vez que só com a Lei da Boa Razão (18 de Agosto de 1769) o Direito Canónico foi remetido para os tribunais eclesiásticos ${ }^{99}$.

97 Constituições do Bispado Deuora, op. cit., (Constituição xj - Que os seguros por razão de morte não entrem nos lugares do malefício durante o seu livramento) fl. $72 \mathrm{v}$.

98 Constituições synodaes do bispado de Coimbra, op. cit., fl. 91v.

99 “aos Meus sobreditos Tribunais, e Ministros Seculares não toca o conhecimento dos pecados; mas sim, e tão somente, o dos delitos: E ordenando, como Ordeno, que o referido conflito fundado naquela errada suposição cesse inteiramente; deixando-se os referidos Textos de Direito Canónico para os Ministros, e Consistórios Eclesiásticos os observarem (nos seus devidos, e competentes termos) nas Decisões da sua inspecção; e seguindo somente os Meus Tribunais, e Magistrados Seculares nas matérias temporais da sua competência as Leis Pátrias, e subsidiárias, e os louváveis costumes, e estilos legitimamente estabelecidos, na forma, que por esta Lei tenho determinado", Lei 
Sem embargo, a lacuna do ordenamento civil acabou por ser colmatada por um estilo do tribunal supremo, "donde será conveniente que, nos casos em que esta proibição se observa com base no estilo, se acrescente, na própria carta de seguro, uma cláusula acerca disto, para que se evite a escusa da ignorância". Trata-se de uma decisão e parecer da Relação, coligido por Melchior Febo ${ }^{100}$ e referido por Manuel Barbosa -apud Homem Leitão-, que impede a entrada no local do delito, salvo "no tempo de produzir a prova ou de citar as partes; com efeito, o réu poderá então entrar no lugar do delito para produzir as provas da sua defesa ou da sua contrariedade, ou para citar as partes"101.

\section{(iv) Que o acusado seguro se apresente a juízo em pessoa.}

A imposição de o segurado se apresentar pessoalmente a juízo já surge numa lei de D. Afonso IV, sem data, sobre os que ganham cartas de segurança como devem fazer no tempo da segurança. "Porque a elrey he dito que aqueles que del gaanham cartas de seguranças para estarem a direito per dante as justiças das terras, que estes assy seguros nom fazem al tam solamente se nom mostram as justiças em no dia que lhys e assynaado em nas ditas cartas, e que dy adeante nom chamam partes, nem estam cada dia a direito nem o seguem assy come homeens acusados de maaos feitos $E$ deuem de estar e seguyr $E$ que per aquel se perde gram parte da iustiça delrey", teve el-rei por bem e mandou que: (i) o seguro que não comparecer no dia assinado na carta de seguro seja logo preso e, na condição de preso, seja ouvido e desembargado; (ii) se o seguro aparecer no dia aprazado, os juizes mandem-lhe chamar as partes ou pessoas que o demandam para se fazer Direito, fixando-lhe o dia em que todos deveriam comparecer a juízo; (iii) se a esse dia não comparecer e não alegar causa justificativa, o seguro seja logo preso e ouvido preso conforme dito; (iv) os juizes ficam obrigados a registar tudo para depois analisar; (v) se os seguros comparecerem, sejam ouvidos pelos juizes no dia que fizerem conselho, desembargando-se os feitos os mais rápido possivel; (vi) e estejam sempre seguros a Direito; (vii) e se assim não fizerem sejam logo presos e não sejam mais soltos até que possam ser livres por Direito; (viii) e se seguirem e fizerem o que devem, sejam-lhe guardadas as cartas de

da Boa Razão, § 12, em http://www.fd.unl.pt/docentes_docs/ma/amh_MA_3847.pdf (consultado a 29 de Outubro de 2013).

100 Decisionum Senatus Regni Lusitaniae, in quibus multa quae in controuersiam quotidie vocantur, grauissimo illustrium Senatorum iudicio deciduntur. Tomus Primus. Auctore Melchiore Phaebo, Lusitano Olysipponensi in suprema Curia aduocato. Excellentissimo Theodosio Duci Brigantino dicatus. Cum facultate Santae Inquisitionis, Ordinarij, \& Regis. Olyssippone : Ex Officina Georgij Roderici. Anno M.DC.XXIII, Arestum CLVIII, p. 70, em http:/ / books.google.pt/books?id=aUvW741IlgoC\&printsec=frontcover\&hl=pt-

$\mathrm{PT} \mathrm{E}=$ onepage\&q=carta\&f=false (consultado no dia 26 de Novembro de 2013); Decisionum Senatus Regni Lusitaniae, in quibus multa quae in controuersiam quotidie vocantur, grauissimo illustrium Senatorum iudicio deciduntur. Tomus Secundus. Auctore Melchiore Phaebo, Lusitano Olysipponensi in suprema Curia aduocato. Excellentissimo Theodosio Duci Brigantiae dicatus. Cum facultate Santae Inquisitionis, Ordinarij, \& Regis. Olysippone : apud Petrum Craesbeeck Typographum Regium, Anno M.DC.XXV, Arestum CLXI, pp. 149-150, em http:/ / books.google.es / books?id=1-

hu7b1FL40C\&printsec=frontcover\&hl $=$ es $\# v=$ onepage $\& q=$ carta $\& f=$ false (consultado no dia 25 de Novembro de 2013).

101 Mateus Homem Leitão, Do Direito Lusitano Dividido em Três Tratados, op. cit., pp. 317-318. 
seguro e não sejam presos até que pelo feito se ache tanto contra eles porque o devam ser; (ix) se os juízes prolongarem os feito ou por outra forma agirem maliciosamente, o corregedor lho estranhe e faça Justiça conforme ao feito couber ${ }^{102}$.

Este impositivo legal -de o seguro comparecer pessoalmente a tribunal, não lhe bastando a representação por procurador ${ }^{103}$ - não se repercutiu na compilação de D. Afonso V nem no primeiro sistema de reforma manuelino, surgindo apenas no derradeiro sistema das Ordenações de D. Manuel I. Embora as Constituições do bispado de Évora de 1534 traduzam os mesmos vectores, a redacção é bastante diferente.

OM (1521) 5.42.22-23 - Em que casos
deuem prender os malfeitores, e reber
querelas, e assi dos em que a Justiça haa
lugar, e se apellará por parte da Justiça, e
a cuja custa se fará a acusação

(...) Porem se a parte assi citada se quiser liurar, nom se poderá liurar por seu Procurador, mas parecerá em pessoa nas Audiencias, e nom parecendo nom será ouuido seu Procurador; saluo se o crime porque assi for acusado for tam leue, em que nom caiba moor pena que de degredo temporal, ou di pera fundo, porque em tal caso se poderá liurar por Procurador. Porem esto nom auerá luguar se elle tomar Carta de Seguro, e se com ella apresentar, porque em tal caso posto que o crime seja muito leue, sempre será obriguado parecer em Juizo, e nom parecendo nom será ouuido por Procurador.

\footnotetext{
OM (1521) 5.1.11 - Da ordem que o julgador tera nos feitos crimes.

...assi como esses seguros ou presos sem licença espeçial dos juizes perante quem andarem, os quaes nom lha daram sem causa euidente e neçessaria...
}

\section{CE (1534) 28 - Das querelas $e$ denunciações}

Constituiçam .xij. Que o seguro sigua seu feito em pessoa, e nom seja a elle, nem ao accusador alleuantadas as residencias sem euidente e necessaria causa

mandamos que ho que tomar carta de seguro seja obrigado a aparecer em pessoa em juizo, segundo forma de sua carta, posto que ho crime seja leue em que caiba menor pena que de degredo temporal. E ho vigairo ou juiz do feito lhe nam aleuantar as residências, nem ao querelloso ou accusador sem causa euidente e necessaria.

Apesar da discrepância redactorial, não será despiciendo que os casos de crime leve sejam aferidos, em ambas as normativas, a partir daqueles em que a pena máxima aplicável seja a de degredo temporal - "que nom caiba moor pena que de degredo temporal, ou di pera fundo"- inculcando algum resquício de

102 Lisboa, IAN/TT - Feitos da Coroa, Núcleo Antigo 458 (Foros ou Costumes de Beja), fls. 45v46, em http://digitarq.dgarq.gov.pt/details?id=4182554 (consultado no dia 11 de Novembro de 2013).

103 Cf. Mateus Homem Leitão, Do Direito Lusitano Dividido em Três Tratados, op. cit., pp. 310313. 
comunicação entre si. O mesmo se diga para a "causa euidente e neçessaria", que consta no outro título das Ordenações e já vinha do primeiro sistema (1512/13).

As Constituições de Braga de 1538 acrescentam, no final deste título, uma ressalva às mulheres estarem residentes às audiências ${ }^{104}$. Mas a excepção já vinha do primeiro sistema das Ordenações Manuelinas (1512/13), mantendo-se na versão final destas Ordenações (1521).

OM (1521) 5.1.11 - Da ordem que o julgador tera nos feitos crimes.

\section{CB (1538) 31 - Das querellas e denunciações}

Constituiçam .xij. Que ho seguro siga seu feito em pessoa e nam sejam a elle nem ao acusador aleuantadas as residencias sem euidente e necessaria causa

E esto no auera luguar nas molheres que acusarem, porque poderam por procurador acusar, assi na primeira instançia, como no caso da apelaçam, dando fiança aas custas e emenda e corregimento, segundo ao julguador pareçer, porem seram obriguados pareçer, quando lhe por os juizes for mandado. saluo se for molher. A qual dando fiança idonea per arbitrio de nossos vigairos de parecer em pessoa quando tho mandarem, ha escusaraa da residencia das audiências

Homem Leitão justifica esta ressalva com a chamada "razão do pudor", fundamentada numa lei do Código de Justiniano (C 2.12.21) ${ }^{105}$.

(v) Que por cada caso se não passem mais de três cartas de seguro.

$\mathrm{Na}$ eventualidade de os segurados quebrarem a sua carta de seguro e não seguirem devidamente os termos processuais, a partir do primeiro sistema das Ordenações de D. Manuel I, é-lhes permitido que a possam renovar, mas até ao limite máximo de três cartas ${ }^{106}$.

\begin{tabular}{c|c}
\hline $\begin{array}{c}\text { OM (152 1) 5.49.3 - Que nom deem Carta } \\
\text { de segurança em caso de feridas abertas } \\
\text { atee passarem trinta dias e em caso de } \\
\text { morte atee tres meses }\end{array}$ & $\begin{array}{c}\text { CE (1534) 28 - Das querelas e } \\
\text { denunciações }\end{array}$ \\
$\begin{array}{c}\text { Constituiçam .xiij. Que por hum caso } \\
\text { nom se possam impetrar mais que ate tres } \\
\text { cartas de seguro }\end{array}$ \\
\hline $\begin{array}{c}\text { Outro si Mandamos, que as pessoas que } \\
\text { as ditas Cartas de seguro pedirem, e as }\end{array}$ & $\begin{array}{c}\text { Item mandamos que as pessoas que as } \\
\text { dictas cartas de seguro pedirem, e as }\end{array}$ \\
\hline
\end{tabular}

104 Constituições do arcebispado de Braga, op. cit., fl. 79.

105 "Maritus citra mandatum in rebus uxoris cum sollemni satisdatione et alia observatione intercedendi habeat liberam facultatem, ne feminae persequendae litis obtentu in contumeliam matronalis pudoris inreverentur inruant nec conventibus virorum vel iudiciis interesse cogantur".

106 Ordenações Manuelina: Livros I a V: Reprodução em fac-símile da edição de Valentim Fernandes (Lisboa, 1512-1513), op. cit., Liv. V, Tít. 42, fl. 32. 
quebrarem, e nom seguirem os termos dellas, possam impetrar atee tres Cartas de segurança dos Nossos Corregedores, e Desembargadores, que para ello sam deputados pera as dar, e conceder; e se a quarta Carta quiserem pedir, e impetrar, nom lhe seja dada sem nosso especial mandado per Nós assinado107. Nas quaes Cartas declarará sempre as que ja quebrou, e d'outra maneira nom lhe valerá a que dereitamente impetrar. E quando assi impetrar a segunda, ou terceira Carta, paguará aas ditas partes as custas do retardamento em dobro, pera que poeram cauçam antes que lhe seja passada a Carta segunda, ou terceira, a qual cauçam será a que pertencer ao que lhe a dita Carta passar, e assi paguará a assinatura da segunda, ou terceira Carta em dobro, se o dito Julguador ouuer de leuar assinatura; e tanto que lhe concedidas forem, tornará a citar as partes, posto que as já teuesse citadas polas Cartas, ou Carta que assi quebrou. quebrarem e nam seguirem os termos dellas, possam impetrar ate tres cartas de segurança, e a quarta lhes non seja dada sem nosso especial mandado.

Em algumas Constituições subsequentes $-v$. g., as de Coimbra de 1548108_ altera-se o limite máximo de cartas de seguro por ocorrência para duas apenas. A lei civil impõe o pagamento de uma caução em duplicado para as despesas do retardamento ao adversário ${ }^{109}$

a. Prazo de validade de três dias para o passe das cartas de seguro.

Só nas Constituições de Braga (1538) me surge um ajuste à lei civil das Ordenações, quanto ao passe das cartas de seguro ${ }^{110}$.

\begin{tabular}{c|c}
\hline $\begin{array}{c}\text { OM (152 1) 5.49.4 - Que nom deem Carta } \\
\text { de segurança em caso de feridas abertas } \\
\text { atee passarem trinta dias e em caso de } \\
\text { morte atee tres meses }\end{array}$ & $\begin{array}{c}\text { CB (1538) } \mathbf{3 1} \text { - Das querelas e } \\
\text { denunciações }\end{array}$ \\
$\begin{array}{c}\text { Constituiçam .x. Como se daram as } \\
\text { cartas de seguro de mortos e feridos (in } \\
\text { fine) }\end{array}$ \\
$\begin{array}{c}\mathrm{E} \quad \text { qualquer pessoa que teuer } \\
\text { desembarguo pera auer Carta de seguro, } \\
\text { poderá com ella andar seguro tres dias }\end{array}$ & $\begin{array}{c}\text { E ho vigairo que passar as tais cartas, } \\
\text { poempre no passe da petiçam ho hora em que se passa. E ho passe }\end{array}$ \\
\hline
\end{tabular}

107 Até aqui coincide com o texto do primeiro sistema das Ordenações Manuelinas: Ordenações Manuelina: Livros I a V: Reprodução em fac-simile da edição de Valentim Fernandes (Lisboa, 1512 1513), op. cit., Liv. V, Tít. 42, fl. 32.

108 Constituições synodaes do bispado de Coimbra, op. cit., fl. 91v.

109 Mateus Homem Leitão, Do Direito Lusitano Dividido em Três Tratados, op. cit., p. 284.

110 Constituições do arcebispado de Braga, op. cit., fl. 78v. 


\begin{tabular}{|c|c|}
\hline $\begin{array}{l}\text { contados do dia que ouuer o } \\
\text { desembarguo, os quaees lhe sam dados } \\
\text { pera tirar sua Carta, sendo a petiçam } \\
\text { conforme aa querela, e passados os tres } \\
\text { dias lho nom guardem sem mostrar Carta } \\
\text { passada pola Chancelaria; saluo se por } \\
\text { culpa, ou impedimento do Escriuam a } \\
\text { nom podesse auer, o qual Escriuam } \\
\text { nesto será crido por seu juramento. }\end{array}$ & $\begin{array}{l}\text { das tays cartas valera aos que has } \\
\text { impetrarem tres dias que segundo } \\
\text { costume tem pera has expedir. }\end{array}$ \\
\hline
\end{tabular}

Este ajustamento vai alternar entre os três e os dois dias nas Constituições subsequentes. O parágrafo 5 da Lei da Reformação da Justiça, de 6 de Dezembro de 1612, revogou este período de validade concedido depois do Passe. Esta revogação civil expressa repercutiu-se na Lei canónica, v. g., nas Constituições de Portalegre de 1632, que em remissão marginal remete directamente para a "lei da noua reformação da justiça $\S 5$ "111.

\begin{tabular}{|c|c|}
\hline Reformação da Justiça (1612) ${ }^{112}$ & $\begin{array}{c}\text { CP (1632) Tit. } 1 \text { - Das acusações, } \\
\text { deuassas e querelas } \\
\text { Capitulo .VI. Das cartas de seguro }\end{array}$ \\
\hline $\begin{array}{l}5 \text { - E para se atalhar aos grandes } \\
\text { damnos, que resultam de valerem Passes } \\
\text { para Cartas de Seguro, não valerá d'aqui } \\
\text { em diante nenhum Passe por si só, nem } \\
\text { dê o Seguro; e servirá somente, para por } \\
\text { elle se fazer a Carta de Seguro; a qual } \\
\text { não valerá, sem ser passada pela } \\
\text { Chancellaria; e os Escrivães começarão } \\
\text { sempre as Cartas na mesma folha, aonde } \\
\text { se pozer o despacho para o Passe }\end{array}$ & $\begin{array}{l}7 \text { - O passe que se dá para carta de } \\
\text { seguro não valerá para effeito de o } \\
\text { culpado não ser preso, mas sómente } \\
\text { seruirá para por elle se fazer a carta de } \\
\text { seguro, a qual será passada pella } \\
\text { Chancellaria. E para euitarmos } \\
\text { inconuenientes, que podem suceder; } \\
\text { mandamos ao escriuão que passar a } \\
\text { carta de seguro a comece sempre na } \\
\text { mesma mea folha ao pé do passe, ou na } \\
\text { volta, não auendo lugar da outra parte } \\
\text { sob pena de suspensão de seu officio }\end{array}$ \\
\hline
\end{tabular}

(vi) Prazo de dez dias para solicitar nova carta de seguro.

Mais um álgida coincidência textual entre o fragmento legislativo civil e o canónico.
OM (1521) 5.1.7 - Da ordem que o $\quad$ CE (1534) 28 - Das querelas $e$ julgador tera nos feitos crimes.

\section{denunciações}

Constituiçam .xiiij. Que dentro em dez dias se possa ho seguro appresentar pera reformar sua carta do dia da residencia quebrada

\begin{tabular}{l|l|l} 
Pero posto que algumas pessoas quebrem & Posto que algumas pessoas quebrem as \\
\hline
\end{tabular}

111 Constituições synodais do bispado de Portalegre, op. cit., fl. $211 \mathrm{v}$.

112 José Justino de Andrade e Silva, Collecção Chronologica da Legislação Portugueza Compilada e Annotada (1603-1612), Lisboa, 1854, pp. 390-391. 
as residençias das cartas do seguro, sobre que andarem a feito, se eles se tornarem a ofereçer em juizo ate dez dias, perante aquelas justiças onde trouuerem seus feytos ordenados, pera os seguirem, os quaes dez dias se contaram, do dia que em juizo nom pareçerem, auemos por bem que nom sejam por ysso presos nem sejam suas cartas de seguro auidas por quebradas, nem seram obriguados a tomar outras cartas de segurança, e esto vindo as ditas pessoas e seguro naquela qualidade que eram, ante do quebrantamento das ditas residençias, pera se deles poder fazer comprimento de dereyto e justiça. residencias das cartas de seguro sobre que andarem a feito, se elles se tornarem a offerecer em juizo ate dez dias, contados do dia que em juizo nom parecerem, nam sejam suas cartas de seguro auidas por quebradas, nem sejam obrigados a tomar outras cartas de seguro. E isto vijndo elles naquella qualidade que eram ante do quebrantamento das dictas residencias, pera se delles poder fazer comprimento de justiça

Esta determinação tem por base um capítulo geral deliberado nas Cortes de Évora de 1490. As Constituições de Coimbra de 1548 diminuem o prazo para apenas oito dias. E no demais impõe que "acerca destes seguros se guarde ho conteudo no regimento de nosso auditorio que esta impresso"113. As Ordenações Filipinas acabam por alongar o prazo até aos quinze dias ${ }^{114}$ e nas Constituições de Leiria de 1601 consta um prazo de dezoito dias.

(vii) Que o seguro não seja preso por quebrar a carta de seguro, se contra ele não existirem fundamentos suficientes para tal.

O primeiro sistema das Ordenações Manuelinas (1512/13) vai introduzir nova regulamentação para as cartas de seguro, no título dedicado à ordem que o julgador deveria ter nos processos crime $^{115}$, que se repercute no sistema seguinte (1521).

OM (1521) 5.1.8 - Da ordem que o julgador tera nos feitos crimes.

\section{CE (1534) 28 - Das querelas $e$ denunciações}

Constituiçam .xv. Que nom seja preso ho seguro por quebrar sua carta, se contra elle nom ouuer culpa, por onde deue ser preso.

E ainda se alguma pessoa andar a feyto por carta de seguro, por razam dalgum maleficio, e quebrar os termos da dita carta, e for requerido que o prendam, por assi quebrar as residências dela, mandamos que em tal caso nom seja
Mandamos que posto que ho seguro quebre as residencias de sua carta, nom seja por ello preso, saluo achandose delle querela, ou proua per que se mostre ou presuma que elle fez ho maleficio, de que se segurou, assi que ha tomada da dicta

113 Trás-os-Montes Medieval e Moderno: Fontes documentais, digitalização e transcrição de Maria Cristina Almeida e Cunha Alegre e Paula Maria de Carvalho Pinto Costa, Bragança, 2003, doc. 99P.

114 Mateus Homem Leitão, Do Direito Lusitano Dividido em Três Tratados, op. cit., p. 314.

115 Ordenações Manuelina: Livros I a V: Reprodução em fac-símile da edição de Valentim Fernandes (Lisboa, 1512-1513), op. cit., Liv. V, Tít. 1. 


\begin{abstract}
preso, se dele nom for querelado por razam do dito maleficio, nem ouuer ainda contra ele proua, porque se mostre, ou presuma, que ele fez o malefiçio de que se segurou, mas deue ser auido como se nunca tomara carta de segurança, e por aquele modo que a justiça podia proceder contra ele, se nom tomara carta de segurança, por esse mesmo proceda em este caso, assi que o tomar da dita carta de seguro, e o quebrantamento dela, o nom obrigue a nenhuma pena.
\end{abstract}

carta de seguro, e ho quebrantamento della, ho nam obrigue a pena alguma.

O lastro desta orientação normativa vem do assento de 15 de Janeiro de 1443, que determinar que deve estar seguro o acusado que se apresenta voluntariamente em juízo, mesmo que não seja titular de carta de seguro'16.

É compreensível que o facto de pedir carta de seguro não sirva como agravante para o acusado. Homem Leitão esclarece que "a transgressão da carta de seguro faz, no máximo, com que o réu se considere como aquele que não tem carta de seguro, e este, se não for culpado e pronunciado, não deve ser encarcerado", mas com ressalva às cartas de seguro confessativas ${ }^{117}$.

Nos decretos saídos do IV Concílio Primaz de Braga, impressos no ano de 1567, ficou estabelecido que os vigários não concedessem cartas de seguro sem prévia consulta ao bispo, em caso de delitos graves dos quais se poderiam seguir escândalos e rixas ${ }^{118}$. Esta decisão vai-se repercutir nas Constituições Sinodais subsequentes - v. g., nas Constituições do Funchal de 1585, "e nos casos graues não passará o dito vigairo geral as taes cartas de seguro, sem primeiro nos dar conta disso"119, ou nas Constituições de Braga de 1639: "E por nenhum caso se passarão cartas de seguro pelo nosso Vigario Geral, nem pelos Vigarios das comarcas, sem primeiro sermos consultado, quando os crimes forem taes, que com razão se devão recear escandalos, brigas, ou bandos, se os que se disser, que cometterão os ditos crimes, confiando nas ditas cartas, forem vistos andar, e tratar livremente nas Cidades, Villas, Lugares, e Freguezias, e ainda nas Igrejas. E se os Vigarios neste caso as passarem sem nosso especial mandado, estranharlhoemos, como nos parecer, que merece seu descuido; e as ditas cartas de seguro serão nullas, e de nenhum vigor, quer sejão negativas, quer confessativas com defesa; $e$

116 Lisboa, IAN/TT - Feitos Findos, Casa da Suplicação, Liv. 1, fls. 28-28v (Livro Antigo das Posses), em http:/ / digitarq.dgarq.gov.pt/details?id=4162670 (consultado no dia 25 de Novembro de 2013); publicado em "Fragmentos de legislação escritos no livro chamado Antigo das Posses da Casa da Supplicação", op. cit., n. ${ }^{\circ}$ 15, p. 560, em https://archive.org/details/collecadeliv03corruoft (consultado no dia 25 de Novembro de 2013.

117 Mateus Homem Leitão, Do Direito Lusitano Dividido em Três Tratados, op. cit., pp. 321-322.

118 Concilium Prouinciale Braccaren. IIII pontificatus sãctiss. D. N. Pij. V. anno 2 regni vero potentiss. pijssimique regis nostri Sebastiani huius nõis primi anno. 10. praeside... patre fratre Bartholomaeo à Martyribus..., Braccarae: apud Antonium â Maris typographum Reuerendiss. D. Archiepi Hispaniarum Primate, 1567, Actio IIII, in fine, cap. 19, fls. 92v-93, em http://purl.pt/23192 (consultado no dia 4 de Outubro de 2013). Cf. Mateus Homem Leitão, Do Direito Lusitano Dividido em Três Tratados, op. cit., p. 261.

119 Constituições synodaes do Bispado do Funchal, op. cit., p. 167. 
O princípio constitucional do habeas corpus no direito canónico português

sem embargo dellas, serão presos os culpados, se estavão nas devassas, querelas, e summarios, pronunciados à prisão"120.

(viii) Alargamento da legitimidade dos prelados ou seus vigários a casos de morte.

A referida decisão de D. Manuel I, de 23 de Julho de 1512, permitindo que o ouvidor do arcebispo de Braga pudesse outorgar cartas de seguro mesmo em feitos de morte, vai, de certa forma, repercutir-se no primeiro sistema impresso das Ordenações do reino (1512-1513). Em suma, as Ordenações acabam por alargar a legitimidade a todos os prelados do reino nestes termos:

\begin{abstract}
"E quanto he aos clerigos dordeens sacras ou beneficiados que gançarem de seos prelados ou de seos vigairos cartas de segurança para estarem perante elles a dereito Mandamos aas nossas justiças que lhes guardem as ditas cartas de segurança que de seos prelados ouuerem. E o *nosso corregedor*121 sendo para ysso requerido lhes dee nossas cartas pera todas nossas justiças que os non prendam $e$ lhes guardem as [ditas] ${ }^{122}$ cartas [de segurança] ${ }^{123}$ de seus prelados. E posto que taes cartas nossas non tenham non seram por ysso presos mas guardar-lhes-ham as ditas cartas de segurança de seos prelados. E esto se fara assi quando *for notorio*124 ou elles perante nossas justiças fezerem çerto que som verdadeiramente beneficiados [conuem a saber, por seu titulo, e por testemunhas, que estam em posse do dito Beneficio, ou que sam d'Ordena sacras, mostrando seu titulo soomentej125 (ou dordeens sacras $E$ sendo pellos juizes eclesiasticos requerido as nossas justiças que lhes enuiem o trelado das querelas e inquirições que de taes clerigos teuerem mandamos que lhos entreguem. E esto soomente do que aos ditos clerigos tocar e non doutras pessoas) ${ }^{126}{ }^{127}$.
\end{abstract}

120 Constituiçoens Sinodais do Arcebispado de Braga, op. cit., p. 523. Com uma remissão marginal para "Concil. Provinc. act. 4 c. 19 pag. 92 vers.".

121 “Corregedor da Nossa Corte”, na edição de 1521 - Ordenaçoens do Senhor Rey D. Manuel, op. cit, Liv. II, Tít. $1, \S 9$.

122 Acrescentado na edição de 1521 - Ordenaçoens do Senhor Rey D. Manuel, op. cit, Liv. II, Tít. $1, \S 9$. $1, \S 9$.

123 Acrescentado na edição de 1521 - Ordenaçoens do Senhor Rey D. Manuel, op. cit, Liv. II, Tít.

124 "quando notoriamente forem conhecidos por Beneficiados, ou d'Ordena sacras, ou nom sendo notoriamente por taees conhecidos”, na edição de 1521 - Ordenaçoens do Senhor Rey D. Manuel, op. cit, Liv. II, Tít. $1, \S 9$.

125 Acrescentado na edição de 1521 - Ordenaçoens do Senhor Rey D. Manuel, op. cit, Liv. II, Tít. $1, \S 9$.

126 Falta na edição de 1521 - Ordenaçoens do Senhor Rey D. Manuel, op. cit, Liv. II, Tít. 1, § 9.

127 Ordenações Manuelina: Livros I a V: Reprodução em fac-símile da edição de Valentim Fernandes (Lisboa, 1512-1513), op. cit., Liv. II, Tít. 1, fl. 2v; O segundo liuro das Ordenações, Lisboa: per Valentym Fernandez alemãao, 1513, em http://purl.pt/14876 (consultado no dia 5 de Outubro de 2013). 
Nas sucessoras Ordenações Filipinas $(1603)^{128}$, que se mantiveram em vigor até ao movimento codificador do século XIX e à entrada em vigor do Código Civil de Seabra (1867), manteve-se, mutatis mutandis, a versão das Manuelinas de 1521 .

\section{CONCLUSÃo.}

As cartas de seguro ou "habeas corpus" português -que "não foi conhecido pelo Direito comum, pois não se faz menção dele em qualquer texto", nem pelo Direito de outras nações, uma vez que os remédios instituídos por estas "diferem profundamente das nossas cartas de seguro"129- seguem, desde as suas remotas origens, duas linhas de acção paralelas: a das cartas de seguro civil e a das cartas de seguro canónico. O paralelismo e as vicissitudes próprias a cada uma dessas linhas não impede, antes pelo contrário, que ambas se tenham relacionado e influenciado mutuamente ao longo dos vários séculos em que este instituto jurídico autóctone esteve em vigor no território português.

É comummente aceite que o relacionamento entre o poder régio e o poder religiosos não foi sempre cordial e pacífico. Em matéria de cartas de seguro, as disputas jurisdicionais dos tempos medievos entre os dois poderes acabam por culminar num reconhecimento geral a todos os prelados do reino, mesmo em feitos de morte, de poderem segurar perante a Justiça os membros da sua Igreja.

A legislação das cartas de seguro canónico surge tardiamente nos textos de Ius proprium das Constituições Sinodais do século XVI. O incipiente acolhimento jurídico dispensado pelas Constituições de D. Diogo de Sousa ao arcebispado de Braga (1506), embora em moldes distintos, tornou-se assíduo nos textos homólogos seguintes, sobretudo os que são impressos a partir do segundo quartel dessa centúria. Nesta abundância quinhentista, terá que ressalvar-se as Constituições da vila de Tomar e outros lugares pertencentes à Ordem de Cristo de 1555, que não cedem nenhuma constituição às cartas de seguro ${ }^{130}$.

O "habeas corpus" canónico multiplica exponencialmente a legis e a praxis em torno deste instituto jusfundamental. Concomitantemente, aumentam as fontes documentais de pesquisa e estudo: desde as fontes legais que aqui ficaram explanadas e outras que venham a surgir $-v$. g., os regimentos dos auditórios eclesiásticos-; às fontes jurisprudenciais $-v$. g., os estilos dos auditórios eclesiásticos-; bem como às fontes doutrinais dos jurisperitos que, com certeza, se não alhearam de matéria jurídica tão relevante no seu tempo $-v$. $g$., as alegações de Tomé Vaz ao título das Ordenações ${ }^{131}$.

128 Codigo Philipino ou Ordenações e Leis do Reino de Portugal recopiladas por mandado d'El-rey D. Philippe I, op. cit., Liv. II, Tit. 1, § 22.

129 Mateus Homem Leitão, Do Direito Lusitano Dividido em Três Tratados, op. cit., pp. 213-214.

130 Constituyções da iurisdiçam ecclesiastica da Villa de Tomar e dos mais lugares que pleno iure pertençem aa ordem de nosso senhor Iesu Christo, Lisboa: Germão Galharde, depois de 12 Janeiro 1555, em http:// purl.pt/15041 (consultado no dia 13 de Outubro de 2013).

131 Thomae Valasci, Allegationes super varias materias: opus omnibus juris pontificii et cæsarei professoribus, judicibus, \& advocatis utile, \& necessarium, 3. ${ }^{a}$ edição, Coimbra: apud Ludovicum Secco Ferreira, 1731, pp. 91-92 e em 246-256, http://almamater.uc.pt/wrapper.asp?t=Thomae+Valasci+\%2E\%2E\%2E+Allegationes+super+varia s+materias+\%3A+opus+omnibus+juris+pontificii + et $+c \% E 6$ sarei+professoribus $\% 2 \mathrm{C}+$ judicibus $+\% 2$ 
O princípio constitucional do habeas corpus no direito canónico português

O paulatino resgate às garras tétricas do esquecimento destes e outros registos históricos -sobretudo, o acervo megalitico de exemplares concretos que devem ter sido outorgados ao longo de mais de cinco séculos de vigência efectiva e os seus livros de registo ${ }^{132}$ - será um inestimável contributo, não só para o princípio constitucional do habeas corpus, mas também para a cultura jurídica portuguesa. Não será, por isso, desajustado terminar com um recurso aos preceitos da actual Constituição da República Portuguesa que, por um lado, determina como tarefa fundamental do Estado "proteger e valorizar o património cultural do povo português" (art. 9, al. e) da CRP) e, por outro lado, impõe a todos os cidadãos "o dever de preservar, defender e valorizar o património cultural" (art. $78^{\circ}$, n. ${ }^{\circ} 1$ da CRP).

Enviado el (Submission Date): 12/11/2014

Aceptado el (Acceptance date): 3/01/2015

6+advocatis+professoribus $\% 2 \mathrm{C}+$ judicibus $\% 2 \mathrm{C}+\% 26+$ advocatis + utile $\% 2 \mathrm{C}+\% 26+$ necessarium $\& \mathrm{~d}=\mathrm{h}$ ttp\%3A\%2F\%2Fbdigital\%2Esib\%2Euc\%2Ept\%2Fbduc\%2FBiblioteca\%5FDigital\%5FUCFD\%2Fdigi cult\%2FUCFD\%2DH\%2DD\%2D21\%2D17\%2FglobalItems\%2Ehtml (consultado no dia 20 de Outubro de 2013). [a 1. a edição é de 1612]

132 As Constituições de Coimbra de 1548 já referem expressamente a existência de um livro de registo para as cartas de seguro - Constituições synodaes do bispado de Coimbra, op. cit., fl. 91-. 